\title{
A Flood Inundation Modeling Approach for Urban and Rural Areas in Lake and Large-Scale River Basins
}

\author{
George Papaioannou ${ }^{1,2,3, *(\mathbb{C})}$, Lampros Vasiliades ${ }^{2}\left(\mathbb{D}\right.$, Athanasios Loukas ${ }^{4, *} \mathbb{C}^{(}$, Angelos Alamanos ${ }^{5}(\mathbb{D}$, \\ Andreas Efstratiadis ${ }^{6}$, Antonios Koukouvinos ${ }^{6}$, Ioannis Tsoukalas ${ }^{6}$ (I) and Panagiotis Kossieris ${ }^{6}$ \\ 1 Hellenic Centre for Marine Research, Institute of Marine Biological Resources and Inland Waters, Anavyssos, \\ 19013 Attiki, Greece \\ 2 Department of Civil Engineering, School of Engineering, University of Thessaly, 38334 Volos, Greece; \\ lvassil@civ.uth.gr \\ 3 Studies Program of the Department of Forestry and Natural Resources Management of the Former \\ Technological Institute of Thessaly, General Department (Larisa), University of Thessaly, \\ 43100 Karditsa, Greece \\ 4 School of Rural and Surveying Engineering, Aristotle University of Thessaloniki, 54124 Thessaloniki, Greece \\ 5 The Water Forum I Centre for Freshwater and Environmental Studies, Dundalk Institute of Technology, \\ Marshes Upper, Dundalk Co., A91K584 Louth, Ireland; angelos.alamanos@dkit.ie \\ 6 Department of Water Resources and Environmental Engineering, School of Civil Engineering, \\ National Technical University of Athens, 15780 Athens, Greece; andreas@itia.ntua.gr (A.E.); \\ A.Koukouvinos@itia.ntua.gr (A.K.); itsoukal@mail.ntua.gr (I.T.); pkossier@mail.ntua.gr (P.K.) \\ * Correspondence: gpapaioan@hcmr.gr (G.P.); agloukas@topo.auth.gr (A.L.); Tel.: +30-22910-76349 (G.P.); \\ +30-231-099-6103 (A.L.)
}

check for updates

Citation: Papaioannou, G.; Vasiliades, L.; Loukas, A.; Alamanos, A.; Efstratiadis, A.; Koukouvinos, A.; Tsoukalas, I.; Kossieris, P. A Flood Inundation Modeling Approach for Urban and Rural Areas in Lake and Large-Scale River Basins. Water 2021, 13, 1264. https://doi.org/10.3390/ w13091264

Academic Editor: Yurui Fan

Received: 4 March 2021

Accepted: 26 April 2021

Published: 30 April 2021

Publisher's Note: MDPI stays neutral with regard to jurisdictional claims in published maps and institutional affiliations.

Copyright: (c) 2021 by the authors. Licensee MDPI, Basel, Switzerland. This article is an open access article distributed under the terms and conditions of the Creative Commons Attribution (CC BY) license (https:// creativecommons.org/licenses/by/ $4.0 /)$.

\begin{abstract}
Fluvial floods are one of the primary natural hazards to our society, and the associated flood risk should always be evaluated for present and future conditions. The European Union's (EU) Floods Directive highlights the importance of flood mapping as a key stage for detecting vulnerable areas, assessing floods' impacts, and identifying damages and compensation plans. The implementation of the EU Flood Directive in Greece is challenging because of its geophysical and climatic variability and diverse hydrologic and hydraulic conditions. This study addressed this challenge by modeling of design rainfall at the sub-watershed level and subsequent estimation of flood design hydrographs using the Natural Resources Conservation Service (NRCS) Unit Hydrograph Procedure. The HECRAS 2D model was used for flood routing, estimation of flood attributes (i.e., water depths and flow velocities), and mapping of inundated areas. The modeling approach was applied at two complex and ungauged representative basins: The Lake Pamvotida basin located in the Epirus Region of the wet Western Greece, and the Pinios River basin located in the Thessaly Region of the drier Central Greece, a basin with a complex dendritic hydrographic system, expanding to more than 1188 river-km. The proposed modeling approach aimed at better estimation and mapping of flood inundation areas including relative uncertainties and providing guidance to professionals and academics.
\end{abstract}

Keywords: EU Floods Directive; flood risk management; extreme rainfall; SCS-CN; 2D hydraulic modeling; HEC-RAS; fluvial floods; ungauged rivers

\section{Introduction}

Natural disasters caused by floods are responsible for the most casualties and economic loss in Europe and worldwide [1,2]. For example, for the period 1995-2015, floods affected 2.3 billion people and costed 157,000 human lives [3]. In general, there are five distinct types of floods (i.e., flash, fluvial, pluvial, urban, and coastal floods), which may stem from various processes and sources. Flood impacts could be aggravated by human activities and interventions in the natural systems (e.g., deforestation, earthworks, water works, urbanization). Fluvial (river) flooding is the most common type of flood and has 
global implications in our society since $50 \%$ of the world's population is close to freshwater bodies [4].

Flood hazard mapping is the process to address flood risk using a combination of structural and non-structural flood risk mitigation measures [5]. According to the EU Directive on floods (E.C. 2007/60), flood inundation mapping and risk assessment should be analyzed through appropriate and effective tools. Such techniques and methods have been presented and discussed in recent review studies [6,7]. Usually, flood hazard mapping encompasses the determination of flood extent from synthetic flood events with typical design return periods (e.g., the 50-year return period flood). However, for accurate flood hazard mapping several other flood characteristics (i.e., flood depth, flow velocity, and rate of rising of the water) should be evaluated [6]. In engineering applications, flood extent and depth are the most common flood characteristics used: The former allows for mapping flood events with typical return periods in a single map, and the latter is directly associated with flood damage [8-10]. Both variables have been mainly assessed using one-dimensional (1D) hydraulic models [11,12]. However, the 1D-modeling method could lead to inaccurate findings under complex flow patterns and in low-relief plain and urban areas. Hence, the use of two-dimensional (2D) hydraulic modeling approaches is usually advocated for accurate flood hazard mapping [13-18].

Greece has been facing increasingly intense and frequent flood events over the last decades; thus, their accurate modeling and mapping is becoming more and more important $[19,20]$. The areas that suffer particularly can be classified into three main categories [21]: (i) Closed hydrological basins, normally drained by natural sinkholes with limited drainage capacity, (ii) plains traversed by complex river systems, and (iii) urban areas, mainly affected by flash floods, where floodplains threaten both wealth and human life. The presence of such catchments, at varying scales, combined with Greece's uneven hydroclimatic regime (wet conditions in the western part of the country and dry conditions in the central and eastern parts), creates a variety of cases that are difficult to be framed under a single modeling approach. Consequently, the implementation of the EU Flood Directive in Greece is challenging in terms of modeling and mapping, and becomes more challenging when considering the inherent uncertainties of hydrological and hydraulic simulations and the limitations in hydro-meteorological and flow data.

The above considerations are among the most popular research questions in the field of flood inundation modeling and mapping [22,23]. Applying hydraulic modeling for flood inundation at a large scale has been addressed by few researchers through coupled hydrologic and hydraulic models [24-29]. Previous relevant works on large-scale systems failed to address some important questions such as: (1) How one can manage a complex river system in which several sub-watersheds outflow to the central stem of a river? (2) How can one deal with a complex river system in which each sub-watershed outflow to a lake and the water of the lake outflow recharges another channel or stream? (3) Is it possible to provide better hydraulic geometry using finer resolution and incorporating several hydraulic structures within the geometry? Additionally, the most common sources of uncertainty are present at each stage of the modeling process, and are associated with: The input rainfall (statistical uncertainty of design storms), the rainfall-runoff transformation (hydrologic uncertainty, in terms of soil moisture conditions, etc.), and the routing process (roughness coefficient is a typical input and an uncertainty source in the hydraulic modeling) [30,31]. Despite the importance of these questions and modeling issues for the implementation of the EU Floods Directive in Greece, there are not any studies, to the best of our knowledge, providing a framework for modeling large-scale basins with complex hydrographic networks and closed basins forming lakes, including rural and urban areas.

This study aimed to address important aspects of the above research questions through a new methodological framework for flood inundation modeling and mapping under uncertainty that follows the EU Flood Directive's requirements. The proposed framework was applied to two Greek basins with different features: (a) The closed basin of Lake Pamvotida located in Western Greece, and (b) Pinios River located in Central Greece, draining a 
large-scale basin with a complex dendritic hydrographic system, expanding to more than 1188 river- $\mathrm{km}$. The stages of the methodology include extreme precipitation modeling at the sub-basin level, using spatially-distributed intensity-duration-frequency (IDF) relationships, and estimation of design hydrographs using the Hydrologic Engineering Center's Hydrologic Modeling System (HEC-HMS), where all time parameters are related to the rainfall intensity, flood routing, and estimation of water depths and velocities by using the 2D Hydrologic Engineering Center's River Analysis System (HEC-RAS), with flexible mesh size for urban areas, and mapping of inundated urban and rural areas of the study basins. Statistical, hydrological, and hydraulic uncertainty factors are assessed by means of scenarios that refer to the parameters of IDF relationships, soil moisture conditions, and roughness coefficients, respectively. It should be mentioned that only fluvial, surface flooding (i.e., lake and/or river overflows) were investigated. These overflows may occur during the rising stage of a flood hydrograph and/or flash floods at the tributaries and during the rising stage of the hydrograph in the main stem of the river and/or lake. Moreover, these overflows are related to widespread, sustained high rainfall and ruptures of natural impoundments (e.g., lakes, lagoons and beaver dams), or artificial impoundments (e.g., obstructed bridges, dams), improper functioning, or rupture of hydraulic structures (e.g., weirs, impoundment dams, reservoirs, artificial levees). The proposed approach presents a general methodology to address the above issues providing a useful reference for flood modeling and mapping analyses using as application examples two study basins, by highlighting their specific features and modeling challenges.

\section{Study Areas}

The modeling approach was applied at two complex and ungauged representative basins: The Lake Pamvotida basin, located in the Epirus Region of the wet Western Greece, and the Pinios River basin located in Thessaly Region of the drier Central Greece (Figure 1). Western Greece is the wettest region of the country, whereas the eastern and central regions of Greece are much drier. The Pindus Mountain range, which runs from the north to the south of mainland Greece, and the general moving direction of storm systems from west to east, creates this spatial variability of precipitation (Figure 1). In general, Greece has a variety of Mediterranean climate subtypes due to the complex topography, which affects the stability of the moist air coming from Central Mediterranean Sea (Figure 1) [32]. Both basins include rural areas, small settlements, and two major cities, i.e., Ioannina city and Larisa city, which are located on the bank of Pamvotida Lake and the main channel of Pinios River, respectively (Figure 2A,B). The above description makes clear the different features of the study areas and how challenging they are in terms of hydrologic and hydraulic modeling. The modeling approach presented in the following sections applies to both closed lake basins, and large-scale basins with complex and extended hydrographic networks. In both cases, the urban areas are approached separately from the rural areas, in accordance with the EU Flood Directive.

\subsection{Lake Pamvotida Catchment}

Lake Pamvotida is located in a closed basin covering an area of $340 \mathrm{~km}^{2}$, placed in Epirus Region, Northwestern Greece (Figure 2A). Most of the basin's runoff flows through small streams and torrents into the lake and a smaller portion of the runoff is diverted to the adjacent Kalamas River basin (to the northwest). The city of Ioannina, which is located at the middle of the western bank of the lake (Figure 2A), is the administrative center and the largest city of the Epirus Region. Its population is about 112,500 inhabitants, according to the 2011 census. 


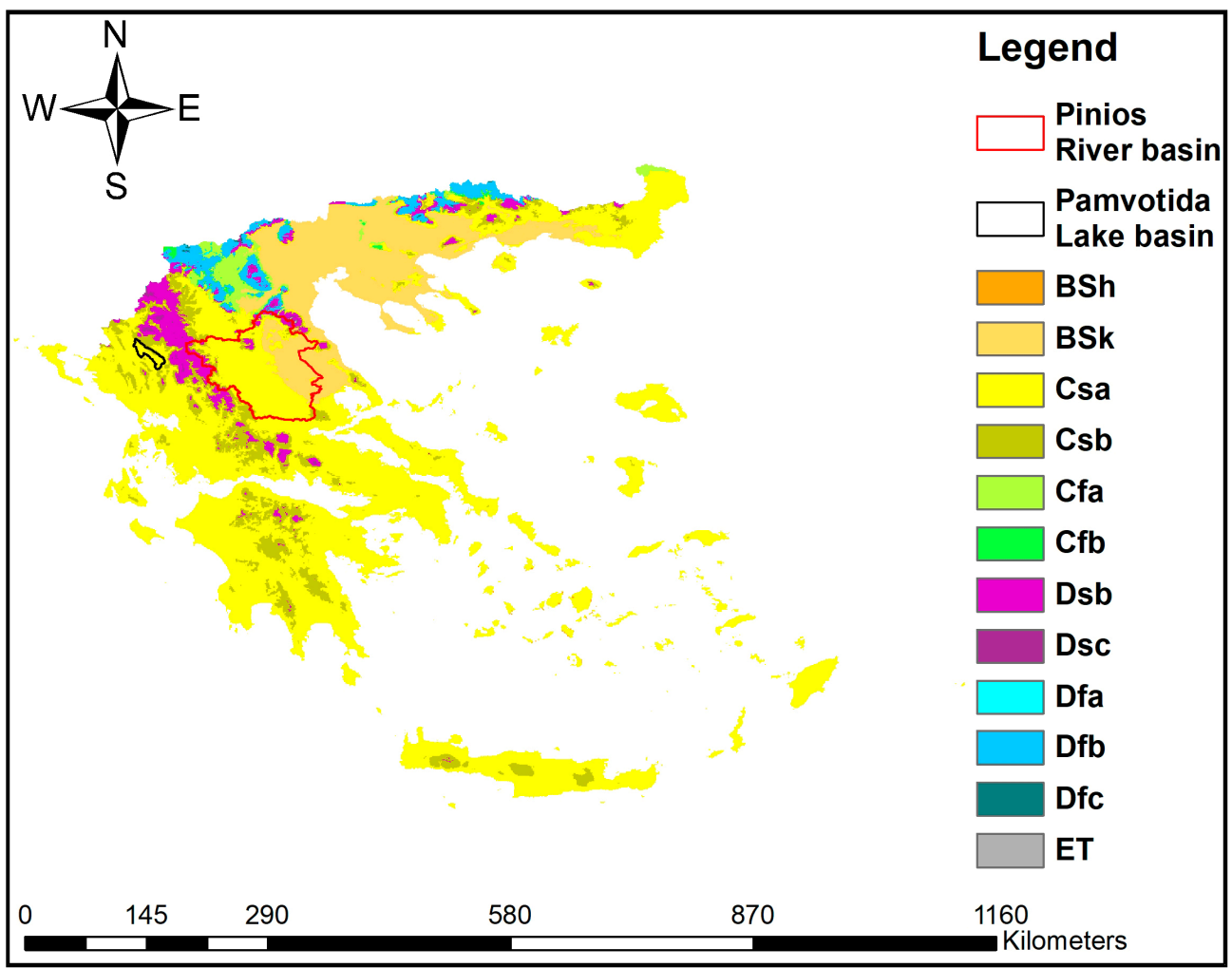

Figure 1. Greece Köppen-Geiger climatic zones [33]. The study areas of Pamvotida Lake basin (black line) and Pinios River basin (red line) are indicated in the map.

The study area's hydro-lithological conditions were derived from the Management plans of flood risks for river basins in Epirous Region (Special Secretariat for Water and Ministry of Environment and Energy (SSW-MEE), 2018) [34]. Lake Pamvotida basin is covered by high to very high permeable formations (45\%), followed by medium to low permeability formations (38\%), very low to zero permeability formations $(9 \%)$, and low permeability formations ( $8 \%$ ). The basin's altitude ranges from 469 to $1808 \mathrm{~m}$, with average elevation of about $680 \mathrm{~m}$. The land cover classification used in this study was based on CORINE land-cover data. The main land cover classes prevailing at Lake Pamvotida basin are forested and semi-natural areas (44\%) and agricultural areas $(42.5 \%)$, followed by artificial surfaces $(6.5 \%)$, water bodies $(6 \%)$, and wetlands $(1 \%)$.

The climate is mild, generally warm and temperate, with very rainy winters and dry summers. The average annual temperature is $13.2^{\circ} \mathrm{C}$. The average annual precipitation is about $1080 \mathrm{~mm}$, with 123.7 rainfall days/year. The rainiest seasons are late autumn, winter, and spring [35]. Mountainous areas of Epirus region are characterized by winters with high precipitation. Summer is cool with irregular rainfall activity. It is the wettest area of Greece [36,37]. Extreme weather conditions are the main cause of flooding at the study basin. In Ioannina city and the small island of Lake Pamvotida, houses were damaged and roads were flooded due to lake overflows in the 9 December 2014 and 14 November 2017 events [38,39]. The flooding processes and flood mapping studies for the study area are very limited, to the best of our knowledge. 


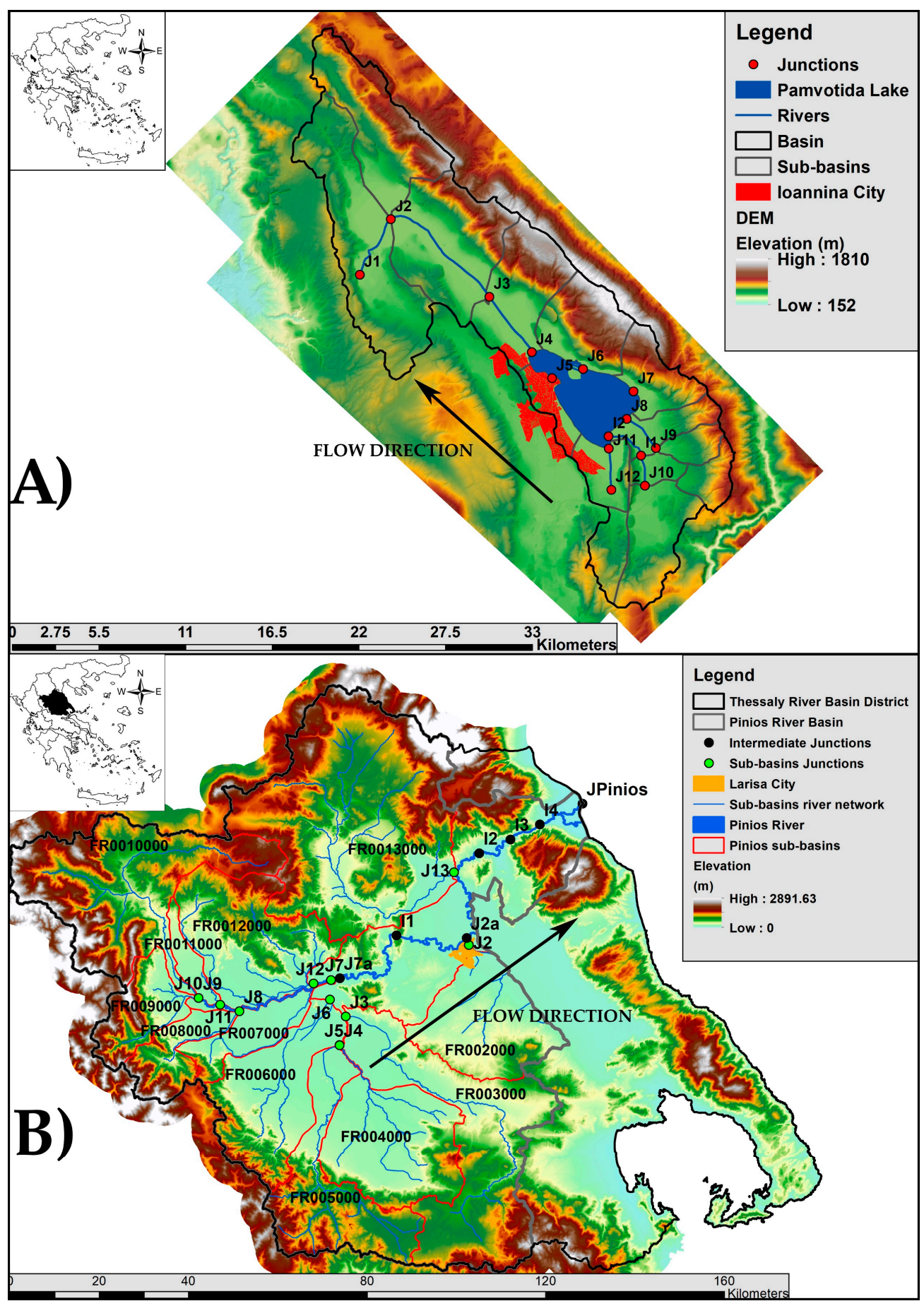

Figure 2. Study areas: (A) Pamvotida Lake basin and (B) Pinios River basin.

\subsection{Pinios River Basin}

Pinios River basin extends over an area of $9664 \mathrm{~km}^{2}$ and is located in Central Greece, covering most of the area of Thessaly water district (TWD) (Figure 2B). The length of the main stem and the tributaries of Pinios River is estimated to be more than $1188 \mathrm{~km}$, while the main channel is, approximately, $196 \mathrm{~km}$ long. Larisa city is located at the middle of the main channel of Pinios River (Figure 2B). It is one of the largest cities of Greece, and the financial and administrative center and the largest city of Thessaly Region. Its population is about 284,500 inhabitants, according to the 2011 census. 
The climate of the basin is typical Mediterranean. The average annual rainfall and reference evapotranspiration are approximately 700 and $1400 \mathrm{~mm}$, respectively. Thessaly region's average annual precipitation ranges from about $400 \mathrm{~mm}$ at the central plain area to more than $1850 \mathrm{~mm}$ at the western mountain peaks where the Pinios river originates [40]. The mean annual streamflow at the river delta is approximately $80 \mathrm{~m}^{3} / \mathrm{s}[41,42]$. Western and Central Thessaly have a continental climate with hot summers and cold winters with large temperature variation. The coastal area of Thessaly has a typical Mediterranean climate. Summers in Thessaly are usually very hot and dry, and in July and August temperatures can reach or even exceed $40{ }^{\circ} \mathrm{C}$ [40]. Thessaly is the largest continuous agricultural productive plain of the country, and at the same time the driest water district of Greece, which experiences frequent droughts and extreme rainfall events causing severe floods $[40,43]$ that disrupt its productivity [44,45].

The area's hydro-lithological conditions have been derived from the management plans of flood risks for river basins in Thessaly region (Special Secretariat for Water and Ministry of Environment and Energy (SSW-MEE), 2018). Pinios River basin is covered by medium permeability formations $(42 \%)$, followed by very low to zero permeability formations $(23 \%)$, low permeability formations $(19 \%)$, high to very high permeable formations $(12 \%)$, and low permeability formations $(4 \%)$. The central part of the basin is covered by a large fertile plain of an area of about $4000 \mathrm{~km}^{2}$. The major cultivated crops are cotton, winter wheat, maize, and alfalfa. The Pinios River basin altitude ranges from 0 to $2085 \mathrm{~m}$, with average elevation of about $440 \mathrm{~m}$. The land cover classification used in this study was based on CORINE land-cover data. The main land cover classes prevailing at Pinios River basin are the agricultural areas (50.8\%) and the forested and semi-natural areas $(45.9 \%)$, followed by artificial surfaces $(2.7 \%)$, water bodies $(0.5 \%)$, and wetlands $(0.1 \%)$.

Pinios River basin is known from the antiquity by the geographer Stravon for its floods, when the first protection works were structured. Besides the construction of a complex system of drainage channels, stream-lining works, and land reclamation projects, already by the end of the 19th to the early 20th century, several parts of the basin are still prone to flooding [42]. Today, Thessaly region is considered as the most vulnerable in Greece, since the potential flood zones cover the $31.2 \%$ of its area (i.e., 4172 of the $13,377 \mathrm{~km}^{2}$ of the TWD) [46]. Quite often, extended inundations occur over the floodplains, resulting in significant damages to the agricultural production, with characteristic examples being the recent events of February 2018 and September 2020. The middle stem of Pinios River, which is located between the flow stations of Ali Efenti and downstream of Amygdalia (Figure 2B, from J7 to I1 and on) and extends over a length of $40 \mathrm{~km}$ and on, is one of the major flood-prone areas of Pinios river basin. This river reach is located $15 \mathrm{~km}$ upstream of Larissa city. Furthermore, flooding in the Thessaly plain is usually intensified due to narrow passes along the main river watercourse and Tempi valley. Deforestation and urbanization also play an important role in increasing the destructive power of floods, thus inducing severe soil erosion problems. Thus, the interest of this study was focused on the main watercourse of the Pinios River. Flooding could be attributed to the inadequate natural discharge capacity across large parts of the river, or the improper design of hydrotechnical projects (i.e., inadequate height of several bridges crossing the river, the construction by farmers of "handy" barriers in the river channel for storage of irrigation water). Finally, the low terrain elevation of the drainage network increases the flood risk at the study area. Historical flood events have been recorded and archived by the Ministry of Agriculture, the Ministry of Environmental, Physical Planning and Public Works, and the Public Power Corporation during the last thirty years. The area around the junctions that are located at rivers Kalentzis (Figure 2B, J6), Enipeas (Figure 2B, J3), Farsaliotis (Figure 2B, J4), Sofaditis (Figure 2B, J5), and Pinios (Figure 2B, J7) is of a high flood risk area. Most scholars so far have focused on the analysis of the past events characteristics and the flood monitoring, rather that the modeling and mapping of flood events in the entire basin $[19,20,47]$. 


\section{Methodology}

This study used integrated flood hazard modeling and a mapping framework developed for ungauged watersheds. The single event-based deterministic approach proposed by Papaioannou et al. [48] was adopted, comprising three modeling components: (i) Synthetic storm generator; (ii) hydrological simulation model; and (iii) hydraulic simulation model [48] (Figure 3). Figure 3 presents the flow chart of the general flood inundation modeling approach followed in this study. This was employed for three typical design return periods ( $T=50,100,1000$ years), assuming that the flood hazard is determined by the input rainfall return period. The mathematical details can be found in the article by Papaioannou et al. [48], where emphasis is given on the hydrological analyses and the mathematical-theoretical background of hydraulic simulations. This paper focused on the application of the framework to ungauged lake and large-scale complex river basins including urban, sub-urban, and rural areas, which involve the hydraulic-hydrodynamic model's adaptation to specific conditions. Its successful implementation is expected to help water resource managers and decision makers to improve the design procedures for flood risk management of closed-lake basins and large-scale complex river basins, and may lead to more efficient flood mitigation strategies.

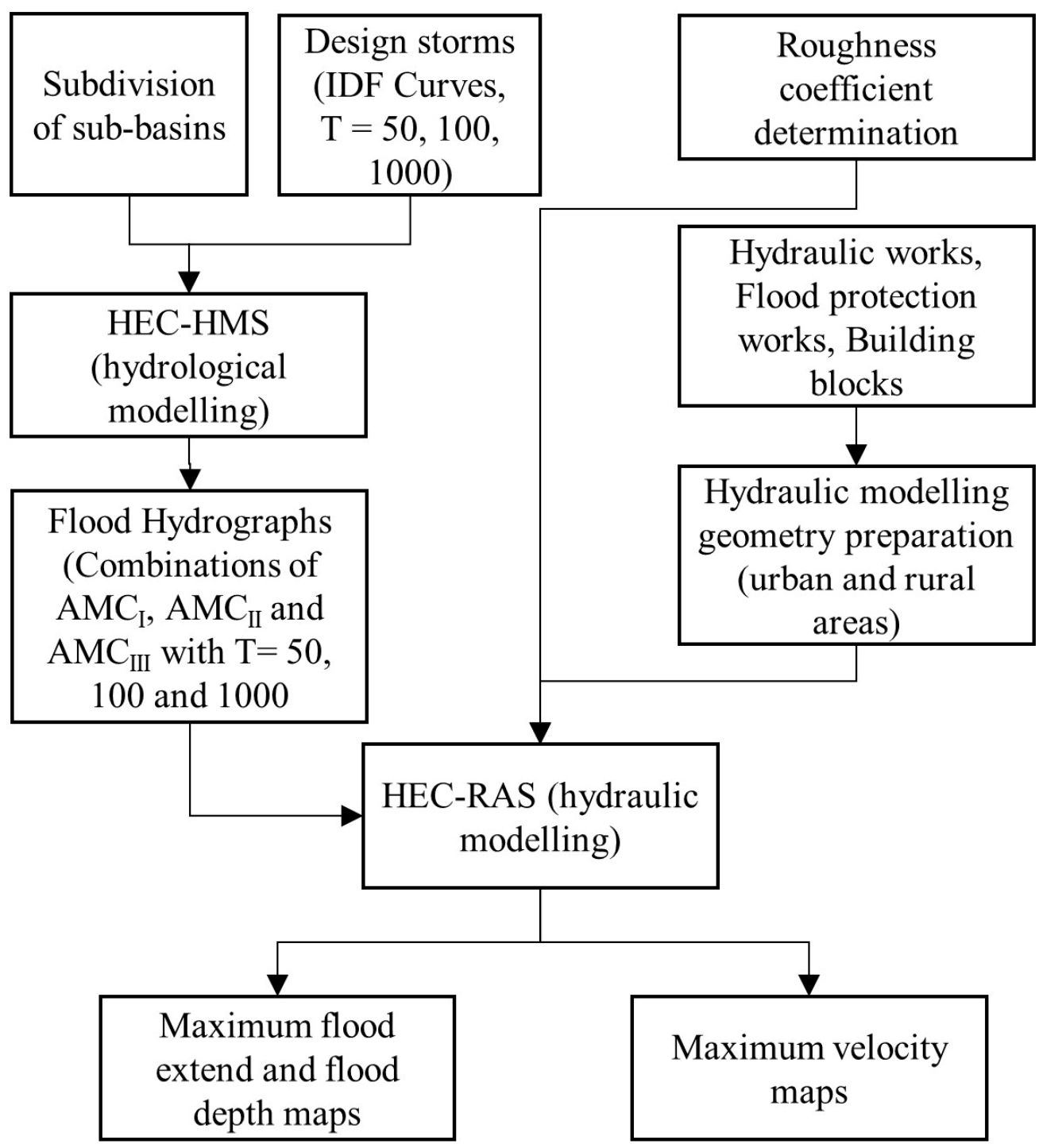

Figure 3. Flow chart of the general flood inundation modeling approach. 


\subsection{Design Rainfall and Hydrological Modeling}

This section presents the hydrologic modeling of the framework, comprising two parts, i.e., a storm generator and a rainfall-runoff model, providing the "computational output" (hydrographs) to be used as an input into the hydraulic model. To account for the heterogeneity of the storm regime, a semi-distributed approach was followed, allowing different rainfall inputs and model parameters to be assigned across sub-basins and to reach elements. The procedure for extracting design hyetographs across sub-basins initiated with the estimation of partial rainfall depths for all temporal scales and return periods of interest, on the basis of spatially-averaged IDF relationships [49] for standard design rainfall durations $(D=24 \mathrm{~h}$ for small-medium scale watersheds and $\mathrm{D}=48 \mathrm{~h}$ for large ones). The areal IDF relationships used here were obtained from the implementation of the EU Flood Directive 2007 / 60 across the River Basin District of Thessaly [48]. Design storm hyetographs were formulated with two typical time profiles, the alternating block method, for $T=50$ and 100 years, and the worst profile method, for $T=1000$ years [50-52]. These were next adjusted by using the areal reduction method; namely, a dimensionless parameter that was defined as the ratio of areal to point rainfall, and the decreasing function of the area and increasing function of duration [53]. Using averaged IDF parameters and associated confidence limits per sub-basin, design storm hyetographs were calculated for the employed return periods and design rainfall scenarios. The design rainfall estimated by the IDF relationship was assumed to correspond to the average scenario, while its $80 \%$ confidence limits, which were measures of the statistical uncertainty induced by the estimation of IDF parameters from relatively small samples (i.e., annual maximum rainfall data), corresponded to the two extreme scenarios (e.g., low-20\% and high$80 \%$ ) [54]. Details and application of the design rainfall procedure are found in the study of Papaioannou et al. [48].

A typical practice for the concentration time estimation and one quite suitable for reproducing observed peak flood flows followed at ungauged basins is the use of empirical approach of Giandotti $[54,55]$. Thus, in this study, the estimation of the concentration time was based on the empirical approach of Giandotti formula:

$$
t_{c}=\frac{4 \sqrt{A}+1.5 L}{0.8 \Delta z}
$$

where $t_{c}$ is the time of concentration (h), $A$ is the basin area $\left(\mathrm{km}^{2}\right), L$ is the length of the longest runoff distance across the basin $(\mathrm{km})$, and $\Delta z$ is the difference between the mean elevation of the basin and the outlet elevation $(\mathrm{m})$.

Moreover, in order to take account of the dependence of the response time of the basin against runoff, the kinematic wave theory-based semi-empirical formula was employed, considering that $t_{c}$ is inversely proportional to the design rainfall, i.e.:

$$
t_{c}(T)=t_{c} \sqrt{\frac{i(5)}{i(T)}}
$$

where $i(5)$ is the design rainfall intensity for return period $T=5$ years, for which the time of concentration is estimated by the Giandotti formula, and $i(T)$ is the intensity of any higher return period, $T$.

Hydrological uncertainty has been expressed in terms of the three typical antecedent moisture conditions (AMC) that are accounted for in the Soil Conservation Service Curve Number (SCS-CN) approach [56]: Dry (or low- $\mathrm{AMC}_{\mathrm{I}}$ ) represented by $\mathrm{CNI}$, moderate (or average- $-\mathrm{AMC}_{\mathrm{II}}$ ) represented by $\mathrm{CNII}$, and wet (or high- $\mathrm{AMC}_{\mathrm{III}}$ ) represented by CNIII [48]. The transformation of the excess rainfall over each sub-basin to flood hydrograph at the outlet junction (rainfall-runoff model) was achieved using the dimensionless curvilinear unit hydrograph approach of SCS, which is considered the prevailing modeling approach for ungauged basins. A key assumption of the method was the implementation of the concept of varying (i.e., runoff-dependent) time of concentration, which affects the 
shape of unit hydrographs, thus introducing further nonlinearities to overall modeling approach [55]. The HEC-HMS software [57] was used, and the design flood hydrographs from the generated storms were estimated for all scenarios. Details are given in [48].

\subsection{Hydraulic-Hydrodynamic Modeling}

The Hydrologic Engineering Center (HEC) of United States Army Corps of Engineers developed the well-known HEC-RAS model that is used in many studies for 1D and 2D river flood modeling and floodplain management, e.g., [12,58]. The 2D hydrodynamic calculations were based on the 2D diffusive wave equations or the full 2D Saint-Venant equations [59]. The HEC-RAS model employs the sub-grid bathymetry approach, which uses a relatively coarse computational grid and a finer scale information underlying the topography. The sub-grid bathymetry equations are derived from the full shallow water and diffusive wave equations [59]. Fundamental elements for an accurate flood inundation modeling and mapping, especially across large-scale and complex watersheds, are the digital elevation model (DEM), the stream channel geometry (river flowpaths, banks, etc.), the hydraulic model configuration (i.e., initial and boundary conditions, roughness coefficients, technical works), and the representation of urban areas by considering the effect of the building blocks to the water flow [60].

Several scholars [12,61-64] have highlighted the importance of DEM accuracy, especially when a 2D hydraulic-hydrodynamic model is used [65]. In this study, we applied a DEM with a resolution of $5 \mathrm{~m}$, provided by National Cadastre and Mapping Agency S.A. (NCMA). Roughness is a well-known input in flood inundation modeling and mapping, as well as a major source of uncertainty. The selection of the appropriate methodology for its reasonable mapping is of key importance $[66,67]$. The most common approach for large-scale applications is the use of typical values based on land use data, as suggested in the literature, combined with CORINE land cover data [42] for the floodplains, as made in this study (Figure 4). Haltas [68] studied the roughness coefficient calibration and showed that the use of a constant value for concrete surfaces, $n=0.04$, could provide acceptable results. Therefore, a weighted roughness coefficient value was used for small size urban areas such as villages $(n=0.03-0.04)$. Typical or "average" channel roughness values were extracted from river photographs, taken upstream and downstream of each technical river work, and riverine areas, aerial photographs examination (provided by NCMA), and the proposed literature values $[42,67,69]$. As explained herein, in order to account for channel roughness uncertainty, the average values of Figure 4 were adjusted by $\pm 50 \%$.

All hydrotechnical works (e.g., flood protection works, culverts, bridges, weirs) within the river and the adjacent areas were detected using aerial photographs, field observations, and data gathered from local authorities. Furthermore, accurate topographical surveys were conducted for the refining of important hydraulic structures [48]. All this information was used for the improvement and/or correction of the DEM to depict accurately all of the important hydraulic structures. In particular, the representation of bridges within the twodimensional (2D) HEC-RAS model has been accomplished by employing a combination of weirs and culverts, modified in the RAS-Geometry routine.

Urban flood inundation modeling and mapping remain a challenge because of the diverse impacts of flooding over these areas (social, economic, fatalities) and the complexity of the system. Recent studies focus on the building representation within the 2D hydraulichydrodynamic model for realistic simulation of flood inundation in urban areas [70-73]. The major building treatment methods are building resistance (BR), building block (BB), building hole (BH), and building parameter (BP) [73]. The BR method involves the local rise of the roughness coefficient value. $\mathrm{BB}$ and $\mathrm{BH}$ are similar, whereas in the $\mathrm{BB}$ method the building is represented using the local rise of the elevation, while in $\mathrm{BH}$ the building blocks do not participate in the computational mesh of the hydraulic model. The BP method allows the water to flow within the block, usually with the application of an area reduction factor (i.e., percentage of flooding participation in the building) [71,73]. Recent evidence $[71,72]$ has revealed the advantages and drawbacks of the building treatment 
methods; thus, further effort needs to be carried out to verify the optimum building treatment method. Here, the building block (BB) approach was eventually used, in which the value of Manning's roughness coefficient for roads was set from 0.013 to 0.015 .

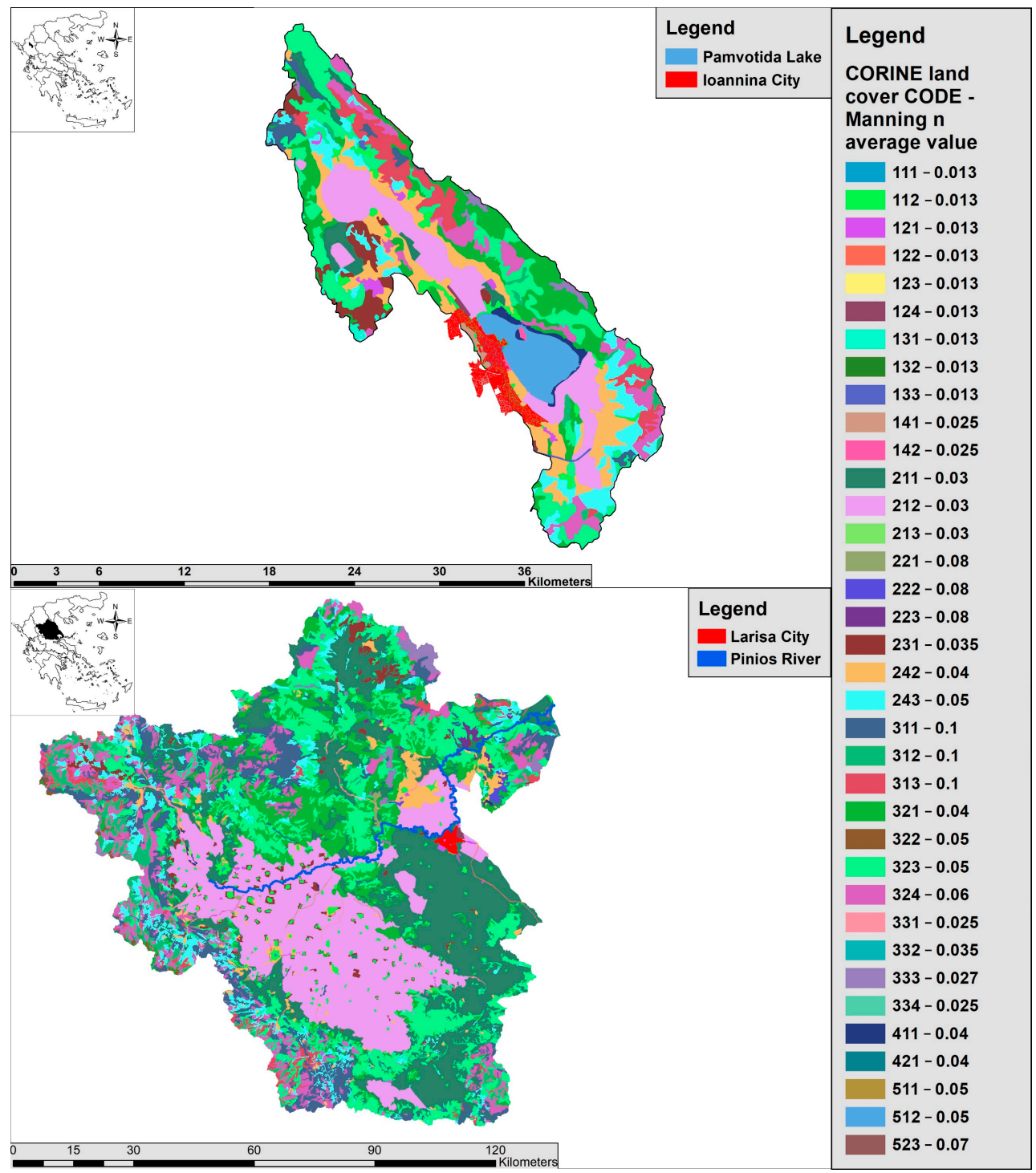

Figure 4. Average values of Manning's roughness coefficient based on CORINE land cover data for Pamvotida Lake (top map) and Pinios River (bottom map) basins.

\subsection{Representation of Uncertainties}

Overall, in the context of flood inundation and mapping, the developed approach can quantify the major sources of uncertainty: (1) Statistical uncertainty associated with the parameters of IDF relationships (i.e., scale and location parameters), originating from limited samples of observed extreme rainfall data; (2) hydrologic uncertainty associated with the soil moisture conditions of the hydrological model, resulting to a wide range of the key input parameter of the SCS-CN method, i.e., the potential maximum retention; and (3) hydraulic-parametric uncertainty associated with Manning's roughness coefficient, which is a typical input parameter of hydraulic flow routing models.

In this study, for each return period of interest ( $T=50,100,1000$ years), three scenarios were implemented (herein referred to as dry, average, and wet), to model joint rainfall and hydrological uncertainties. Specifically, it was assumed that the design rainfall estimations provided by the IDF relationship corresponded to the standard average scenario, while 
its $80 \%$ confidence limits, which were measure of rainfall uncertainty (more precisely, parameter uncertainty of the IDF expression), corresponded to the two extreme scenarios. Hydrological uncertainty was expressed in terms of three typical antecedent soil moisture conditions (dry, normal, wet) that were employed within the rainfall-runoff modeling approach. Hence, the $\mathrm{CN}$ values for dry, and wet conditions, combined with the low and upper $80 \%$ confidence limits of rainfall, were used to generate design hyetographs that capture the uncertainty around the "standard" average hydrologic conditions (standard IDF design rainfall estimations combined with normal antecedent soil moisture conditions). These uncertainty components were combined, thus resulting in nine (9) operational scenarios (Table 1). Furthermore, to include the uncertainty of the Manning's roughness coefficient, "upper" and "lower" boundaries of the estimated values were included in the two extreme scenarios. In this context, the estimated roughness values which correspond to average hydraulic conditions (Table 1 ) were adjusted by $-50 \%$ and $+50 \%$, to represent the upper and lower bounds of this parameter and implemented only in the two extreme scenarios as shown in Table 1.

Table 1. Operational scenarios modeled to provide uncertainty bound estimations.

\begin{tabular}{ccc}
\hline Return Period & Hydrologic Conditions & Roughness Coefficient Conditions \\
\hline T50 & Dry $\left(\mathrm{AMC}_{\mathrm{I}}\right)$ & $-50 \%$ Estimated \\
T50 & Average $\left(\mathrm{AMC}_{\mathrm{II}}\right)$ & Estimated (Average) \\
T50 & Wet $\left(\mathrm{AMC}_{\mathrm{III}}\right)$ & $+50 \%$ Estimated \\
\hline T100 & Dry $\left(\mathrm{AMC}_{\mathrm{I}}\right)$ & $-50 \%$ Estimated \\
T100 & Average $\left(\mathrm{AMC}_{\mathrm{II}}\right)$ & Estimated (Average) \\
T100 & Wet $\left(\mathrm{AMC}_{\mathrm{III}}\right)$ & $+50 \%$ Estimated \\
T1000 & Dry $\left(\mathrm{AMC}_{\mathrm{I}}\right)$ & $-50 \%$ Estimated \\
T1000 & Average $\left(\mathrm{AMC}_{\mathrm{II}}\right)$ & Estimated (Average) \\
T1000 & Wet $\left(\mathrm{AMC}_{\mathrm{III}}\right)$ & $+50 \%$ Estimated \\
\hline
\end{tabular}

\section{Application of the Methodology}

Despite the technological advancements in 2D hydraulic modeling, flood inundation modeling using 2D approaches is still a time-consuming and demanding task. On the other hand, the model selection depends on the importance of the flooded areas (e.g., urban area, rural areas) and the output data requirements. Thus, in cases where the use of a 2D model is mandatory, the modeling procedure and its methodological steps can be a highly challenging issue. The following paragraphs present the design and implementation of specific methodological assumptions in two challenging systems to overcome some of the 2D hydraulic modeling limitations.

\subsection{Application of the Modeling Methodology to the Study Basins}

In this section, the specific adjustments of the general methodological framework and its application to the two study areas are described, as a reference point and guidance to future studies on similar areas. The main idea argues in favor of flexible modeling, as the only way to cope with the specific features of each given area. Thus, these adjustments refer to each stage of the procedure: Hydrological, hydraulic-hydrodynamic, and the differences between rural and urban areas.

The two types of examined cases with the accompanying modeling challenges are:

- Closed basin-lakes, where the hydrographic network does not end at a single junction (i.e., the basin's outlet); thus, the standard procedure for river network systems needs to be adapted. As explained below, the "exit" point (outlet) was represented by assigning a "virtual" junction at the center of the lake;

- Large-scale basins with complex and extended hydrographic networks, which are unavoidably subject to huge computational load, thus requiring significant computational time and resources. To tackle these impediments, a two-stage approach was followed, involving the numerical modeling for each main tributary, and use 
of the associated outflow hydrographs as inputs for the hydraulic simulation of the main river.

Concerning the hydraulic modeling application, it is noteworthy to mention that the Flood Directive (2007/60/EC) implementation in Greece has been implemented in two steps. The first step was to undertake Preliminary Flood Risk Assessments (PFRA), leading to the identification of areas that are at significant risk of flooding, known as areas of potential significant flood risk (APSFR) [74]. Consequently, flood hazard and risk maps (FHRM) were generated within the ASPFR in order to depict (in terms of water depth, velocity, flood extent, etc.) the impact of flooding that can affect human health, the economy, environment, and cultural heritage $[74,75]$. Therefore, flood inundation modeling was implemented only within the ASPFR areas.

\subsection{Modeling of Pamvotida Lake Basin}

Pamvotida Lake basin is a closed basin, where the surrounding sub-watersheds are drained into the lake, from which a small percentage of the basin's runoff is diverted to the adjacent Kalamas River. The hydrological model domain consists of 15 sub-basins, 13 junctions, and 11 stream reaches, while the hydraulic-hydrodynamic model domain consists of eight (8) stream reaches (total length $47 \mathrm{~km}$ ) and the lake (Figure 2A). As explained above, the hydraulic-hydrodynamic model configuration is restricted to these 8 reaches because the flood inundation modeling was applied only within the APSFR areas.

The model domain comprises two components, i.e., the lake inflow and the lake outflow. The inflow sub-domain comprises the simulations conducted with direction in the lake system (river reaches that contribute to the lake), while the lake outflow sub-domain involves the simulations with direction from the lake to the outside domain (the water that overflows from the lake to adjacent areas and channels). Therefore, the lake basin consisted of two independent hydraulic sub-systems: The downstream one (4 sub-basins) that receives water from the lake, and the upstream one (10 sub-basins) that drains into the lake. A single hydraulic geometry modeling configuration (i.e., the simulation from the lake to the adjacent areas) was adjusted for urban flood inundation modeling for the area of Ioannina city. Considering the lake as an individual system, the outflows from all tributaries were set as input discharges to the lake. The lake's simulation set aimed to route the flow through the lake and provide the outflow at junction J4 (Figure 2A). Specifically, the inflow sub-domain consisted of the hydraulic-hydrodynamic simulation of the runoff that directly enters into the lake (five inflow nodes, J5, J6, J7, J8, and J11).

Moreover, the outflow sub-domain consisted of the hydraulic-hydrodynamic simulation of the outflow from the lake to the adjacent areas (one junction, J4, and several outflow boundary lines, Figure 2A). Therefore, the lake simulation results (discharges at the outflow areas) were used as inflows for flood modeling of the adjacent areas and the downstream sub-system (location J4). In junction J4, the water transfers to the downstream sub-system using water gates. The mechanism of the outflow sub-domain initiates when the lake is at the bankfull stage. Thus, when the lake water surface rises up to the water stage set by the regulating sluice gate, then part of the stored volume overflows to the downstream sub-system (from J4 to J1), and then it is diverted to another river basin (Kalamas River basin) through a canal that exists in J1 (Figure 2A). Sixteen (16) technical works (e.g., bridges, culverts) were surveyed and included in the digital topographical domain (revised DEM), and their effects on the flow are simulated. The generated mesh details for all hydraulic modeling domains are presented in Table 2. 
Table 2. Generated mesh details for each junction at the two study watersheds.

\begin{tabular}{|c|c|c|c|c|}
\hline \multicolumn{5}{|c|}{ Pinios River Basin } \\
\hline Junctions & Min Cell Size $\left(\mathrm{m}^{2}\right)$ & Average Cell Size $\left(\mathrm{m}^{2}\right)$ & Max Cell Size $\left(\mathrm{m}^{2}\right)$ & Number of Mesh Cells \\
\hline I1 to J2 & 3.56 & 350.82 & 1536.65 & 897,152 \\
\hline I4 to Jpinios & 2.23 & 396.19 & 1136.40 & 201,837 \\
\hline $\mathrm{I} 2$ to I3 & 3.15 & 170.52 & 355.7 & 136,643 \\
\hline $\mathrm{J} 2$ to $\mathrm{J} 13$ & 3.29 & 584.18 & 1300.55 & 1368,293 \\
\hline $\mathrm{J} 3$ to J6 & 11.1 & 461.99 & 1320.13 & 380,244 \\
\hline J6 to J7a & 9.75 & 434.43 & 912.19 & 298,897 \\
\hline J7a to I1 & 2.53 & 469.85 & 1599 & 259,480 \\
\hline $\mathrm{J} 7$ to $\mathrm{J7a}$ & 2.97 & 603.23 & 1715.99 & 473,104 \\
\hline $\mathrm{J} 8$ to $\mathrm{J} 12$ & 2.83 & 619.13 & 1337.19 & 1402,636 \\
\hline $\mathrm{J} 11$ to $\mathrm{J} 8$ & 3.7 & 566.87 & 1122.98 & 948,058 \\
\hline $\mathrm{J} 12$ to $\mathrm{J} 7$ & 17.99 & 605.26 & 1145.23 & 448,332 \\
\hline $\mathrm{J} 4 \mathrm{~J} 5$ to $\mathrm{J} 3$ & 19.21 & 564.43 & 1252.93 & 630,411 \\
\hline J9J10 to J11 & 2.32 & 315.89 & 606.39 & 751,988 \\
\hline \multicolumn{5}{|c|}{ Lake Pamvotida Basin } \\
\hline Junctions & Min Cell Size $\left(\mathrm{m}^{2}\right)$ & Average Cell Size $\left(\mathrm{m}^{2}\right)$ & Max Cell Size $\left(\mathrm{m}^{2}\right)$ & Number of Mesh Cells \\
\hline J12 to J11 & 7.39 & 179.65 & 879.34 & 45,238 \\
\hline I1 to I2 & 1.35 & 244.5 & 984.16 & 53,535 \\
\hline J10 to I1 & 4.47 & 325.88 & 726.51 & 19,547 \\
\hline $\mathrm{J} 2$ to $\mathrm{J} 1$ & 2.44 & 404.22 & 871.58 & 42,038 \\
\hline $\mathrm{J} 3$ to $\mathrm{J} 2$ & 2.3 & 403.84 & 1064.81 & 82,064 \\
\hline $\mathrm{J} 9$ to $\mathrm{J} 8$ & 25.01 & 352.98 & 890.89 & 32,221 \\
\hline LAKE & 355.53 & 628.6 & 1643.88 & 35,345 \\
\hline LAKE OUT/J4 to J3 & 0.94 & 206.98 & 1634.75 & 396,026 \\
\hline
\end{tabular}

\subsection{Modeling of Pinios River Basin}

The hydrological and hydraulic model of the Pinios River basin consists of $12 \mathrm{sub}-$ basins, 12 junctions, and 13 stream reaches (total length of about $196 \mathrm{~km}$ ), including the Pinios River main channel (Figure 2B). The sub-basin areas range from 94 to $1902 \mathrm{~km}^{2}$ and their total area is approximately $8410 \mathrm{~km}^{2}$. The runoff from the sub-basins is routed through a number of major tributaries to the main channel of Pinios River. The outlet of Pinios River basin is at the Pinios Delta where the river outflows to the sea. The upstream part of the basin consists of 10 sub-basins, covering about $70 \%$ of its total area (Figure 2B), while the downstream part consists of only two (2) sub-basins (Figure 2B). The modeling system comprises twelve (12) junctions and six (6) intermediate nodes that work as junction points for multiple flood hydrographs and/or as midpoints. The main channel is divided into thirteen (13) main reaches that involved within ASPFR and were simulated using the two-dimensional (2D) hydraulic-hydrodynamic model. However, separating certain reaches from the rest of its hydrographic network, to comply with the ASPFR rules, creates a challenge regarding the accurate estimations of their initial flows. For that purpose, we simulated separately the reaches that are not included within ASPFR zones, by applying the 1D hydraulic-hydrodynamic model for the upstream parts, and then setting their outputs as inputs to the zones included within the ASPFR (downstream parts). More specifically, the (upstream) reaches between the nodes I3 to I4 and J13 to I2 were simulated using the 1D approach to provide inflow hydrographs to the downstream areas that extend over the ASPFR zones (reaches between junctions I2-I3 and I4-JPinios, Figure 2B). Hence, the methodological "gap" of the preliminary studies is covered, ensuring more accurate flow estimations for the zones of interest.

The flood hydrographs from the large sub-basins that are drained to Pinios (Figure 2B) were synchronized based on the Muskingum method [76]. Thus, the main channel does not receive the flood hydrographs arriving from its tributaries at the same time. Some subbasins such as FR003000 (J3), FR004000 (J4), FR005000 (J5), and FR006000 (J6) (Figure 2B) are 
not connected directly to the Pinios main channel. In such cases, flood hydrograph routing downwards the main channel was implemented by using the 2D hydraulic-hydrodynamic model. Furthermore, a dimensionless reduction coefficient, $\lambda$, was assigned to each subbasin, $i$, defined as the ratio of the individual areal reduction factor $\varphi_{i}$ for a sub-basin to the global areal reduction factor $\varphi_{\text {Pinios }}$ for the entire Pinios river basin, i.e., $\lambda_{i}=\varphi_{i} / \varphi_{\text {Pinios }}$. In this context, ARFs at all individual sub-basins, as well as the entire Pinios River basin of $9664 \mathrm{~km}^{2}$, are estimated using the empirical formula [53]:

$$
\varphi=1-\frac{0.048 A^{0.36-0.01 \ln (A)}}{d^{0.35}}
$$

where $A$ is the drainage area $\left(\mathrm{km}^{2}\right)$ and $d$ is the rainfall duration (h).

This assumption is based on the following proofs: (1) It is not realistic to assign a point maximum rainfall intensity over large-scale river basins, (2) the larger sub-basins have smaller ARF values, which implies more important reduction in the flood hydrograph, (3) increase in rainfall duration is followed by increase in the areal reduction factor, which means smaller reduction in the flood hydrograph, and (4) the factor depends to some degree on the return period and it seems that the rise in the return period leads to small reduction of the ARF, which means smaller reduction in the flood hydrograph. Hence, the reduction coefficient was estimated for all Pinios River sub-basins (12 sub-basins) and all flood hydrographs multiplied by the corresponding $\lambda$ (sub-basins junctions, Figure 2B, i.e., junction J5 flood hydrograph). Then, the hydraulic simulations of the main channel of Pinios River were performed by using as inputs the final reduced outflow flood hydrographs from the 12 sub-basins (sub-basins, Figure 2B, i.e., FR004000, FR003000).

Moreover, in certain cases, the flood hydrographs were merged because the outlets of some sub-basins were too close or at even the same location, or where there were multiple inflow junctions (e.g., see J9 and J10, Figure 2B). Thus, the routing was implemented as a reach-by-reach procedure, where the outflows of certain sub-basins were used as the inflows to the downstream reach, and the simulated outflow hydrograph of a reach was used as an inflow hydrograph in the following (downstream) stream reach simulation. Furthermore, some parts of Pinios were bisected due to several limitation factors such as the enormous computational time, huge number of mesh elements, or overdemanding computational power (see reaches between junctions J7 to I1 and I1 to J2 in Figure 2B). Finally, 21 technical works (e.g., bridges, culverts, river training works) were digitized and included in the hydraulic-hydrodynamic model domain. For instance, Figure 5 presents the ground survey of Bridge 224 at Drosero (approximately $850 \mathrm{~m}$ downstream from J9 and J10) and how these ground survey data were incorporated into the 2D model (Figure 5A,B). Figure $5 \mathrm{C}$ presents the technical details of the bridge piers and abutments and Figure 5D shows the effect of bridge design in the final mesh generation. Figure 5E,F depicts the water depth and velocity time series at the center of the bridge. The generated mesh details for all modeling domains are presented in Table 2. 


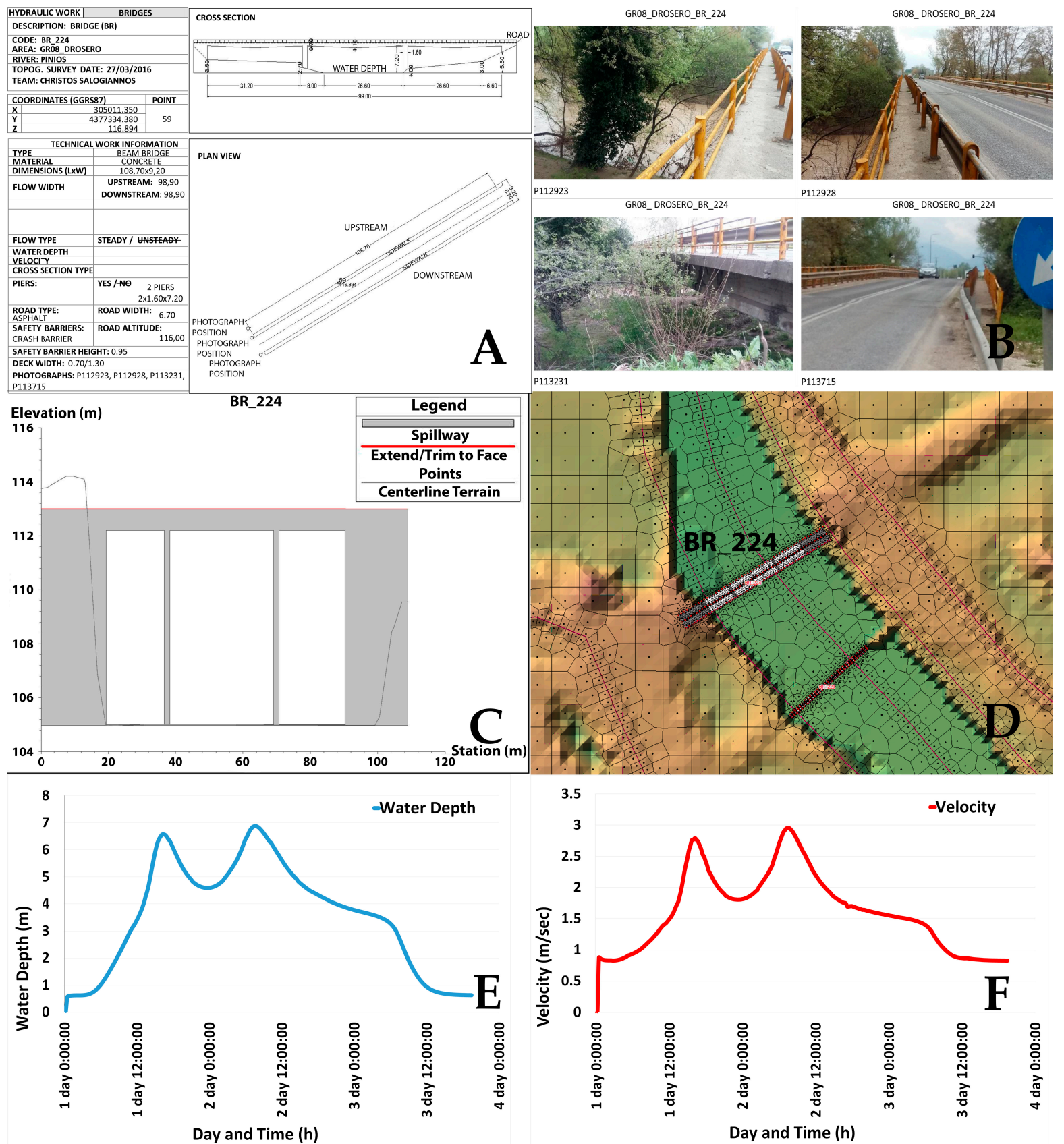

Figure 5. Example of ground survey of bridge (bridge number 224 at Drosero). (A) Topographical survey sketch, (B) photographs from the topographical survey, (C) technical details of the bridge piers and abutments, (D) effect of bridge design in the final mesh generation, $(\mathbf{E})$ water depth, and $(\mathbf{F})$ velocity time series graphs at the center of the bridge.

\subsection{Hydraulic Modeling across Rural and Urban Areas}

Flood inundation modeling and mapping were implemented using HEC-RAS 2D model with variable mesh computation point spacing, from 5 to $25 \mathrm{~m}$. The diffusion wave equations were selected for all applications and a variable computational interval, from 1 to $10 \mathrm{~s}$, was used depending on the stability of each modeling application. The hydraulic-hydrodynamic configurations consisted of standard methods that followed at urban and rural area applications. In most cases, the hydrograph, mapping, and detailed output intervals were set to $15 \mathrm{~min}$. The two categories of boundary condition lines were the inflow and the outflow ones. The former was defined by a hydrograph, while the latter was defined by a normal depth $[59,77]$. 
The input DEM spatial resolution was $5 \mathrm{~m}$, and a local increase of the elevation was implemented in the building block areas of Larisa and Ioannina cities (BB elevation rise method). In order to improve the representation of specific hydraulic structures and flood mitigation works, we used the actual topography of the structures and a DEM editing method that could generate a new surface using the geometry of cross sections (XS interpolation surfaces module of RAS geometry routine) [77]. Several breakline elements were used to provide a different mesh resolution and an accurate representation of (a) the river and its banks, (b) the embankments and other flood mitigation works, (c) the hydraulic structures (e.g., bridges, weirs, culverts), and (d) the building block areas. For the Pinios River basin, two hydraulic geometry modeling configurations (see reaches between nodes I1 to J2, J2 to J13) were adjusted (i.e., through the BB elevation rise method) for urban flood inundation modeling across Larisa city.

\section{Results and Discussion}

The application of the semi-distributed hydrological modeling procedure was carried out for all the AMC scenarios, and the design hydrographs were produced from the HECHMS model. Figure 6 presents, indicatively, a set of inflow and outflow hydrographs of the hydraulic simulation from junctions J9-J10 (inflow, output of HEC-HMS) to junction J11 (outflow, output of HEC-RAS) of Pinios River for average $\mathrm{AMC}_{\mathrm{II}}$. Similarly, all the design hydrographs were estimated for each junction. The design hydrographs were then used as inputs to the hydraulic simulation for all examined hydrologic conditions, return periods, and roughness coefficient scenarios.

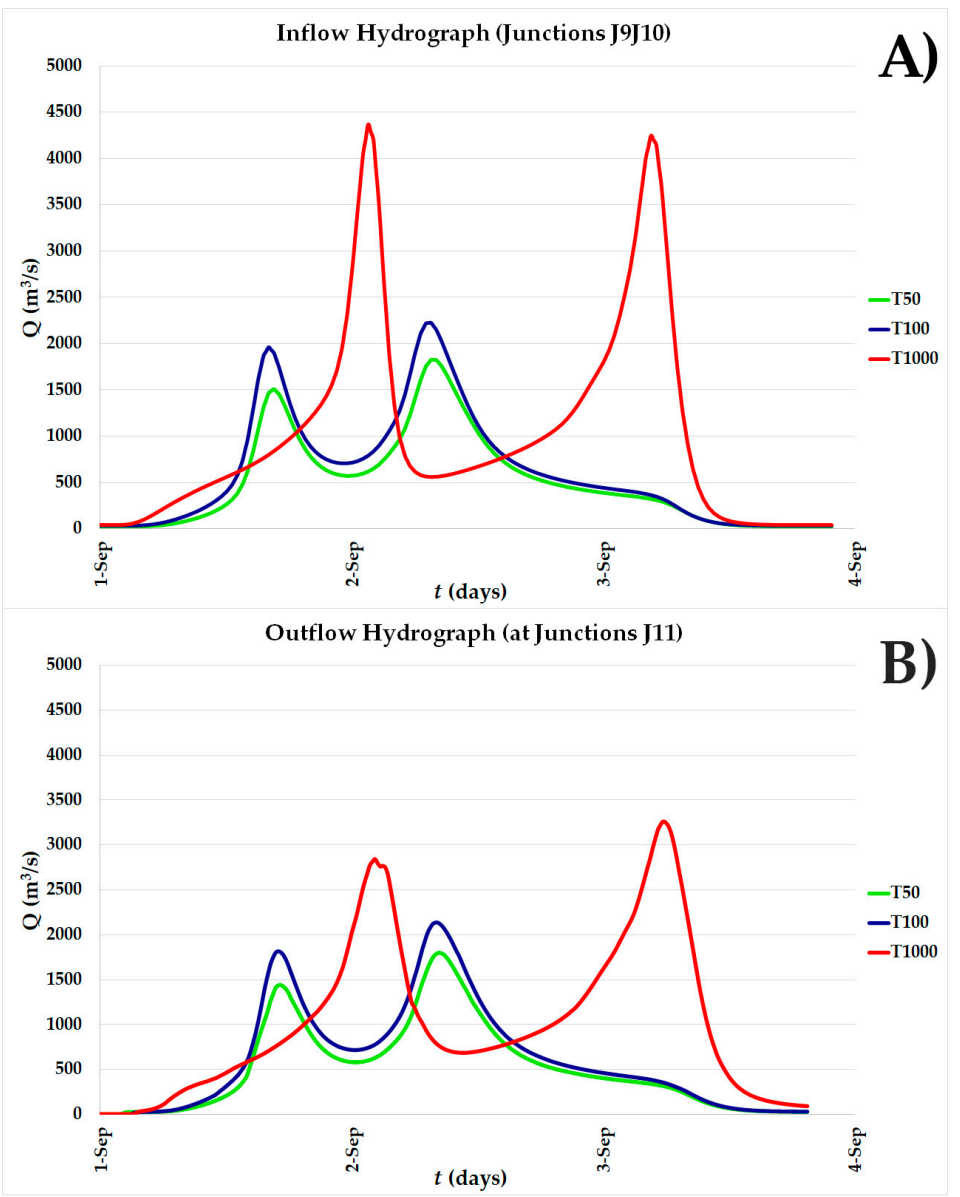

Figure 6. Inflow and outflow hydrographs of the hydraulic simulation from junctions J9-J10 to J11 of Pinios River for average AMCII for all return periods: (A) Inflow (design) hydrograph, (B) outflow hydrograph. 
The focus of this work was on the hydraulic simulation, which used as inputs the produced hydrographs across the stream network. Table 3 presents Pamvotida Lake and Pinios River basins' total flooded area (in $\mathrm{km}^{2}$ ) for all examined scenarios and return periods, while a visual representation of Table 3 is presented in Figure 7 as box and whisker plots. As expected, the extent of inundated areas is increasing with the return period and the change of antecedent soil moisture conditions from dry to wet (Table 3, Figure 7).

Table 3. Lake Pamvotida and Pinios River basin total flooded areas $\left(\mathrm{km}^{2}\right)$ for all examined hydrologic and hydraulic scenarios and all investigated return periods.

\begin{tabular}{ccccc}
\hline \multirow{2}{*}{ Studied Basin } & Hydrologic/Roughness & \multicolumn{3}{c}{ Return Period T (years) } \\
\cline { 3 - 5 } & Coefficient Scenarios & $\mathbf{5 0}$ & $\mathbf{1 0 0}$ & $\mathbf{1 0 0 0}$ \\
\hline \multirow{3}{*}{ Lake Pamvotida } & Dry $\left(\mathrm{AMC}_{\mathrm{I}}\right) /-50 \%$ & 7.89 & 11.47 & 18.17 \\
& Average $\left(\mathrm{AMC}_{\mathrm{II}}\right) /$ Average & 16.34 & 20.06 & 26.69 \\
& Wet $\left(\mathrm{AMC}_{\mathrm{III}}\right) /+50 \%$ & 19.56 & 24.42 & 34 \\
\hline \multirow{3}{*}{ Pinios River } & Dry $\left(\mathrm{AMC}_{\mathrm{I}}\right) /-50 \%$ & 157 & 229 & 463.18 \\
& Average $\left(\mathrm{AMC}_{\mathrm{II}}\right) /$ Average & 340.90 & 481.2 & 731.48 \\
& Wet $\left(\mathrm{AMC}_{\mathrm{III}}\right) /+50 \%$ & 477 & 622.88 & 871.53 \\
\hline
\end{tabular}

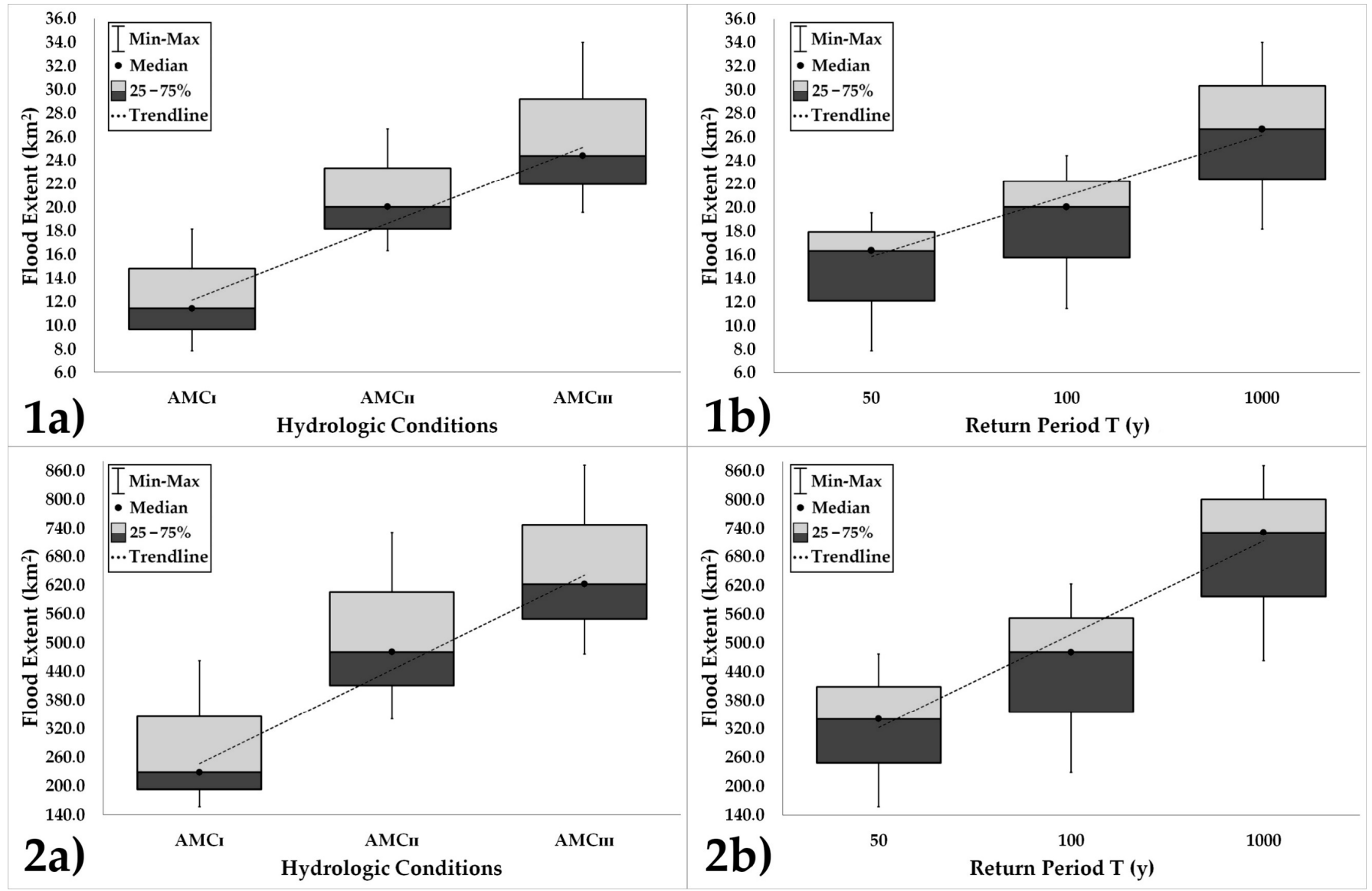

Figure 7. Box and whisker plots based on the total flooded area $\left(\mathrm{km}^{2}\right)$ for all examined operational scenarios. (1) Pamvotida Lake: (a) hydrologic conditions, (b) return period. (2) Pinios River: (a) hydrologic conditions, (b) return period. 
It is interesting to note that based on the flooded area in comparison of the hydrologic conditions, the third quartile $75 \%$ was wider than the first quartile, while in comparison of the return periods, the first quartile $25 \%$ was wider than the third quartile. An important finding revealed from Table 3 and Figure 7 is that the effect of uncertain hydrologic conditions has at least equal significance on the flood inundation area with the return period. The total flood inundation area of Pinios River varies from 157 to $463 \mathrm{~km}^{2}$ for $\mathrm{AMC}_{\mathrm{I}}$, from 341 to $731 \mathrm{~km}^{2}$ for $\mathrm{AMC}_{\mathrm{II}}$, and from 477 to $872 \mathrm{~km}^{2}$ for $\mathrm{AMC}_{\mathrm{III}}$, while the flood inundation area of Lake Pamvotida ranges from 7.9 to $18.2 \mathrm{~km}^{2}$ for $\mathrm{AMC}_{\mathrm{I}}$, from 16.3 to $26.7 \mathrm{~km}^{2}$ for $\mathrm{AMC}_{\mathrm{II}}$, and from 19.6 to $34.0 \mathrm{~km}^{2}$ for $\mathrm{AMC}_{\mathrm{III}}$ (Table 3 and Figure 7). This outcome confirms our previous findings [48] that the generation of a flood is strongly influenced by the soil moisture that is already stored at the beginning of rainfall.

A slight difference is between the flood inundation area of the operational scenarios for the return periods of 50 and 100 years, while a significant difference with the highest flood inundation area values was observed for the 1000-year return period (Table 3, Figure 7). The total flood inundation area of Pinios River varied from 157 to $477 \mathrm{~km}^{2}$ for $\mathrm{T}=50$ years, from 229 to $623 \mathrm{~km}^{2}$ for $\mathrm{T}=100$ years, and from 463 to $872 \mathrm{~km}^{2}$ for $\mathrm{T}=1000$ years, while the total flood inundation area of Lake Pamvotida ranged from 7.9 to $19.6 \mathrm{~km}^{2}$ for $\mathrm{T}=50$ years, from 11.5 to $24.4 \mathrm{~km}^{2}$ for $\mathrm{T}=100$ years, and from 18.2 to $34.0 \mathrm{~km}^{2}$ for $\mathrm{T}=1000$ years (Table 3 , Figure 7).

Figure 8 illustrates the maximum water depth and flood extent for all examined scenarios (all hydrologic conditions and return periods). The distribution of the maximum velocity for the average scenario for all return periods is presented in Figure 9. Figures 8 and 9 refer mainly to the rural parts of the study basins.

Since the simulations of urban areas needed further attention, their results are presented in larger scale maps. Figure 10 presents the maximum water depth and the flood extent within the areas of Larisa and Ioannina cities for all scenarios and for the important return periods considered in urban areas ( $\mathrm{T}=50$ and 100 years). Interestingly, the water depth seemed to be more sensitive than velocity (Figures 8-10). This was a reasonable finding, because the terrain has small slope and thus, the flow velocities were low.

The above results vary significantly due to the wide uncertainty bounds of the flood simulation outputs (peak flows, flood volumes, inundated areas, etc.). The uncertainty bounds overlap the hazard, which is expressed by the return period of rainfall. In particular, the lower and upper estimations may differ by an order of magnitude for large return periods. For this reason, attention should be given in the application of the proposed methodology for specific return periods and the hydrologic-hydraulic conditions. Moreover, the findings of this study highlight the importance of using several scenarios (by means of hydrologic and hydraulic-hydrodynamic configurations) to quantify the associated uncertainty, to select the optimum configuration for flood inundation modeling and mapping, and to use the results for the improvement of flood risk mitigation strategies. Finally, it is noteworthy to mention that the proposed methodological approach has been validated against simulated historical flood event [48] at another ungauged watershed and using post-flood analysis [12]. 


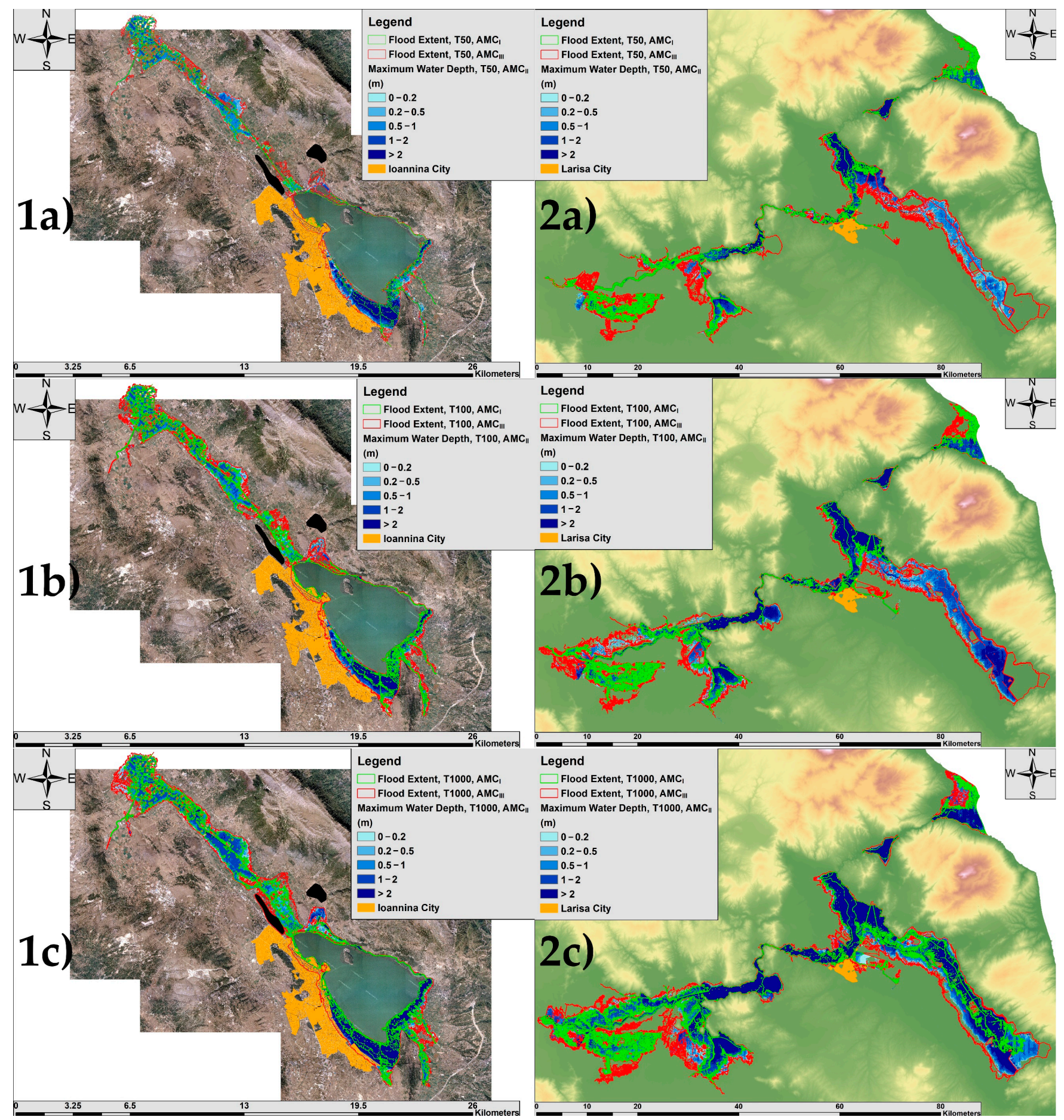

Figure 8. Maximum water depth and flood extent for all examined operational scenarios. (1) Pamvotida Lake: (a) $\mathrm{T}=50$ years, $(\mathbf{b})$ $\mathrm{T}=100$ years, $(\mathbf{c}) \mathrm{T}=1000$ years. $(\mathbf{2})$ Pinios River: $(\mathbf{a}) \mathrm{T}=50$ years, $(\mathbf{b}) \mathrm{T}=100$ years, $(\mathbf{c}) \mathrm{T}=1000$ years. 


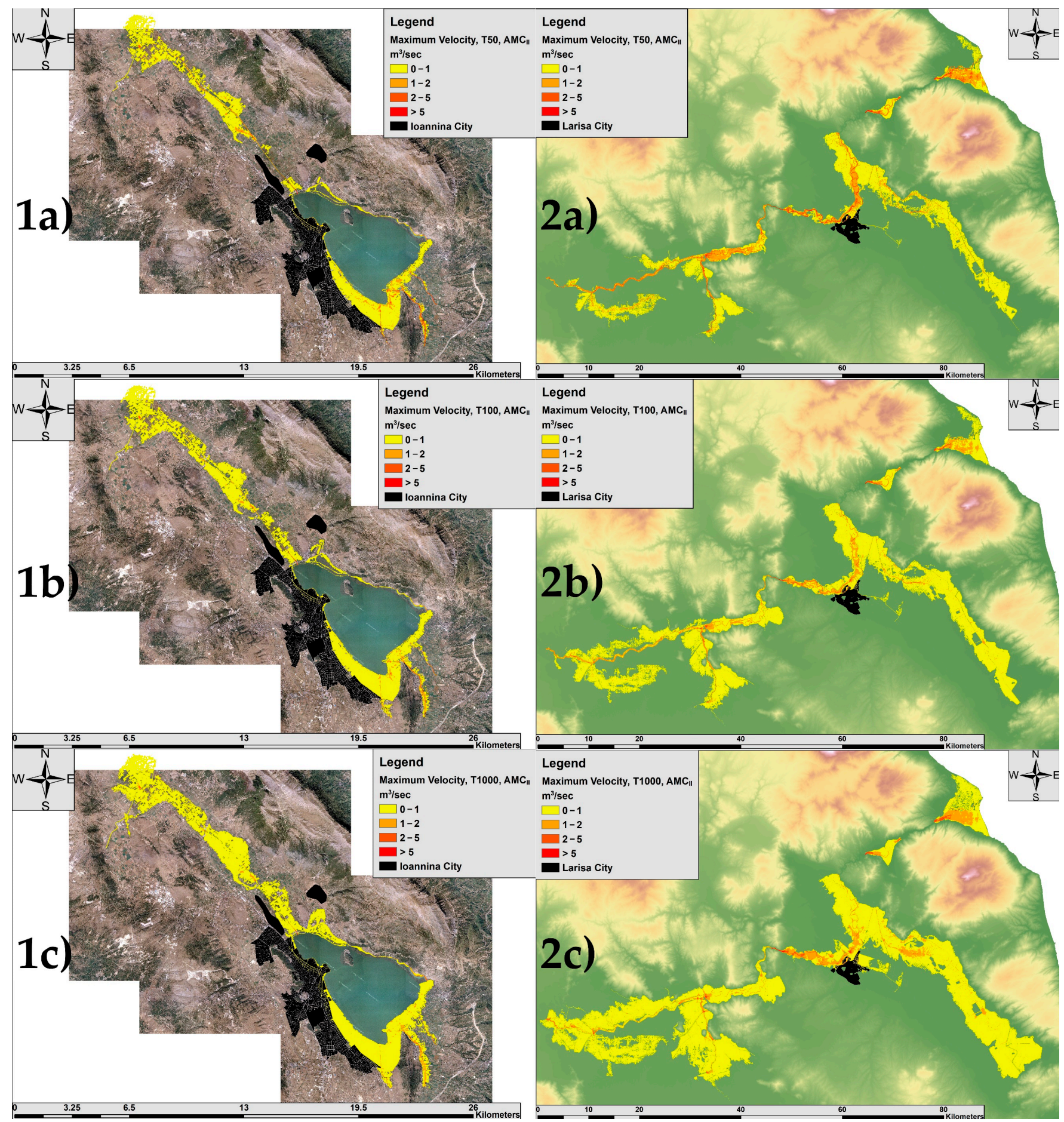

Figure 9. Maximum velocity for the average operational scenario. (1) Pamvotida Lake: $(\mathbf{a}) \mathrm{T}=50$ years, $(\mathbf{b}) \mathrm{T}=100$ years, $(\mathbf{c})$ $\mathrm{T}=1000$ years. (2) Pinios River: (a) $\mathrm{T}=50$ years, $(\mathbf{b}) \mathrm{T}=100$ years, $(\mathbf{c}) \mathrm{T}=1000$ years. 


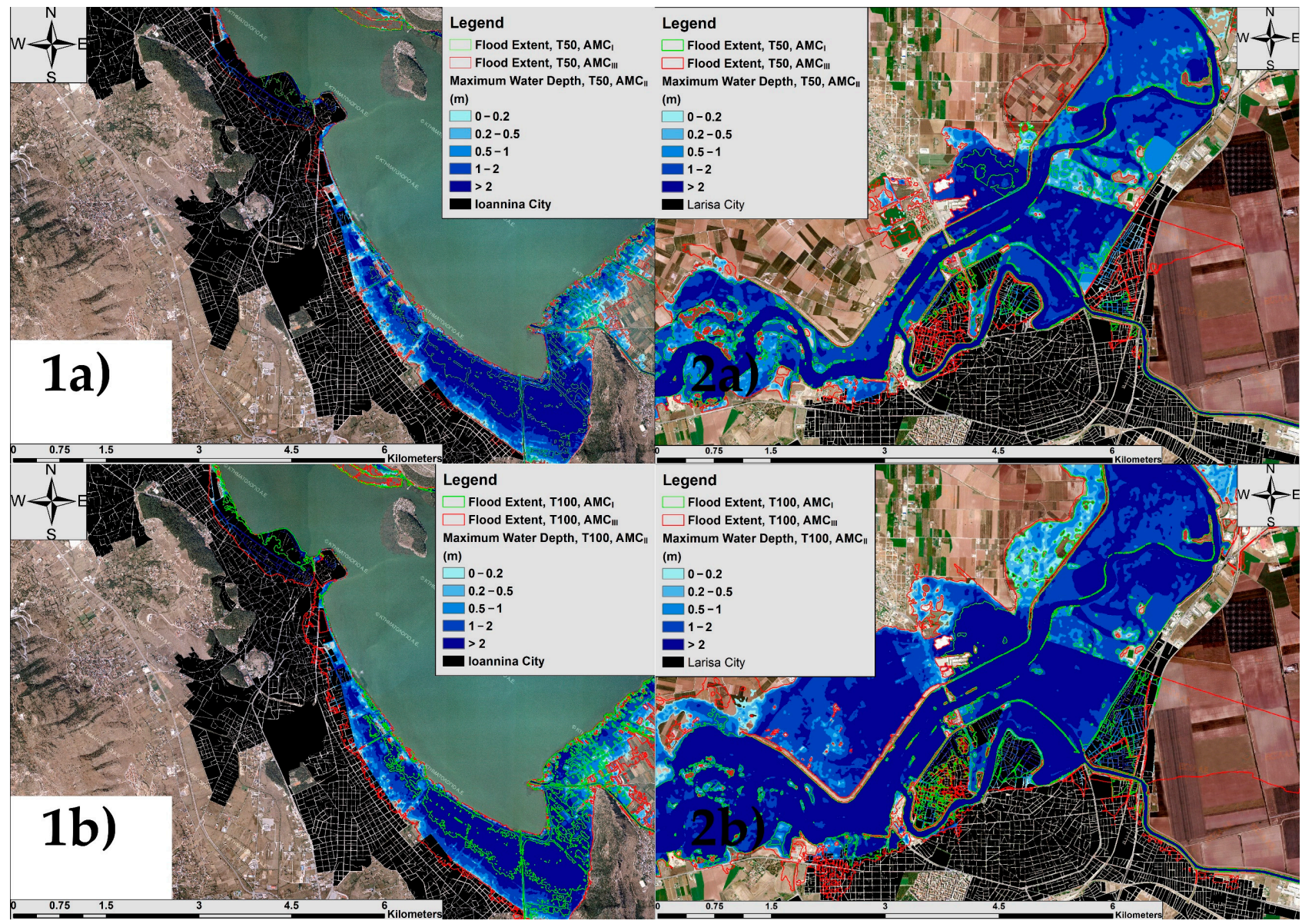

Figure 10. Maximum water depth and flood extent within the cities for all examined operational scenarios. (1) Pamvotida Lake-City of Ioannina: (a) $\mathrm{T}=50$ years, (b) $\mathrm{T}=100$ years. (2) Pinios River-City of Larisa: (a) $\mathrm{T}=50$ years, (b) $\mathrm{T}=100 \mathrm{years.}$

\section{Conclusions}

This paper presented a hydrologic-hydraulic-hydrodynamic computational framework for flood modeling and mapping in ungauged areas. All configurations concerning urban and rural areas were in line with the EU Flood Directive. Each member-state had the versatility in determining the optimum configuration of the framework, customized to their context of flood management, aiming for accurate estimations and representations of potential risks [78].

A limitation regarding its application in Greece is that the national datasets of floodrelated records lack detail, accuracy, and spatial distribution of the recorded flood characteristics (peak flows, water depths, flood extent); thus, typical approaches such as data-driven approaches in flood risk assessment, based on observed floods statistical analysis, were not feasible [20,79]. Typical hydrological and hydraulic methods and flexible modeling settings were counterposed. The input data uncertainties issue was further addressed by using scenario-based approaches (regarding extreme rainfall analysis, antecedent soil moisture conditions, and roughness coefficients). Such scenarios are recommended to estimate upper and lower water depth, velocities, and inundated areas for each return period, thus quantifying the uncertainties introduced by each quantity of interest.

An advantage of this work is that the examples presented cover in general the most flood-prone areas such as closed hydrological basins drained by natural sinkholes with limited drainage capacity, plains traversed by complex river systems, and urban areas. Motivated by the peculiarities of Greek areas in terms of hydraulic simulation, the different case studies were presented as examples to provide guidance on how to address several broader hydraulic-hydrodynamic modeling concerns. Although using more than one 
case study increases the working effort, it is recommended for testing a model (as a generally applicable design framework). The proposed approaches and the main hydraulichydrodynamic modeling configurations are generalized and summarized in Table 4 . Their results provide all the necessary elements for flood management.

Table 4. Hydraulic-hydrodynamic configurations and techniques recommended for the modeling of rural and urban areas in closed lake basins and large-scale complex river basins.

$\begin{array}{ll}\text { Recommendations for } & \text { Description-Steps } \\ \text { Each modeling Category } & \end{array}$

- Make necessary DEM modifications (e.g., at urban areas, building representation using local elevation rise BB method)

- $\quad$ Roughness coefficient estimation using CORINE land cover and engineering standards, and refine with more detailed photos and relevant literature (in

General: For rural and urban areas Goal: Increase accuracy and facilitate computations certain parts)

- The technical works (bridges, culverts, embankments, etc.) were configured within the hydraulic-hydrodynamic geometry configuration

- Consider different case studies with different features to test the model as a framework

\begin{abstract}
Case 1: Closed basins with limited drainage

Specific goal: Address areas that do not have an "exit" point as outlet of the catchment (i.e., outlet is considered as a bankfull lake). Thus, areas such as lakes, can be examined on their water-expansion under the conditions imposed by the design storms
\end{abstract}

(1) Hydrologic modeling of lake tributaries drained into the lake

(2) Flood inundation modeling of lake tributaries (general recommendations)

(3) Two different simulation approaches (lake inflow and lake outflow simulations) were conducted for the lake system

o The lake was simulated as a closed system, as well as its outflows to adjacent areas. The inflows were added from its outer boundaries, as the surplus of their normal flow conditions, while the outlet is considered to be a virtual junction in the center of the lake

o Simulation of flood inundation of rural and urban areas adjacent to the lake (general recommendations)

(1) Hydrologic modeling of river tributaries and estimation flood inflow to the river

(2) Merging flood hydrographs in confluence junctions (step-by-step procedure)

Case 2: Large-scale regions with complex hydrographic network

Specific Goal: Address huge computational requirements maintaining the desirable accuracy

(3) Simulate the river's upstream, then re-estimate flood inflows for downstream

(4) Simulate flood inundation of following part of the river

(5) Simulate flood inundation of urban areas

(6) For large rivers, follow an iterative procedure, by repeating steps 3 and 4 until the simulation of the final part of the river

\section{Uncertainty}

Goal: Improve the model, be aware of values' range, warn for uncertainty sources
- Develop scenarios by detecting the most important sources of uncertainty (e.g., extreme rainfall estimations, antecedent soil moisture conditions, roughness coefficients)

- Include them in the modeling procedure and examine the uncertainty bounds

Although the limitation regarding large computational time for large-scale areas remains, it provides accurate estimations since it is a step-by-step procedure that uses very fine mesh resolution. The successful implementation of the proposed framework is a valuable advance for the improvement of flood risk mitigation studies and indicates the uncertainty introduced in flood risk management in rural and urban areas using typical engineering practices.

The evidence from this study indicates that the hydrologic analysis's input data uncertainty (e.g., antecedent soil moisture conditions and extreme rainfall estimations) has at least equal significance against the overall flood risk, which is expressed in terms of the return period of the design storm event. Even though the studied input data uncertainty prevailed in the analysis, it is underlined that there were several other sources of uncertainty within the hydrologic analysis. Therefore, flood inundation modeling under additional uncertainty scenarios is suggested. 
Actually, there are several other challenges that can be encountered when performing hydraulic-hydrodynamic modeling. However, a key message of this work was the flexibility of the techniques and methods that must accompany the mindset of the analyst when approaching challenging and compelling problems. This is in line with other recent modeling advances, not only referring to floods, and their importance is further highlighted when data limitations need to be addressed [80-82]. The combination of deep knowledge of the theoretical background (conceptually and mathematically) and the computational context (tools) is required, and comes through practice and experience.

Author Contributions: Conceptualization, methodology, formal analysis, writing —original draft preparation, writing-review and editing, visualization, G.P., A.L., L.V. and A.E., writing-original draft preparation, writing-review and editing, visualization, A.A.; formal analysis, A.K., I.T. and P.K. All authors have read and agreed to the published version of the manuscript.

Funding: This research received no external funding.

Institutional Review Board Statement: Not applicable.

Informed Consent Statement: Not applicable.

Data Availability Statement: The data that support the findings of this study are available from the Greek Ministry of Environment and Energy—Special Secretariat for Water (SSW). Specific data can be provided by the corresponding author upon reasonable request.

Acknowledgments: This paper is part of the project "Management Plans of Flood Risks for River Basins in Thessaly, Western Sterea Hellas and Epirus Regions, Greece", co-funded by the EU and the Greek Ministry of Energy and the Environment. This project constitutes the implementation of the EU Directive on Floods (E.C. 2007/60) in the above regions of Greece. The research presented in the paper is partially supported by this project. The valuable comments by the three anonymous reviewers helped to improve the initially submitted manuscript.

Conflicts of Interest: The authors declare no conflict of interest.

\section{References}

1. Berz, G.; Kron, W.; Loster, T.; Rauch, E.; Schimetschek, J.; Schmieder, J.; Siebert, A.; Smolka, A.; Wirtz, A. World map of natural hazards-A global view of the distribution and intensity of significant exposures. Nat. Hazards 2001, 23, 443-465. [CrossRef]

2. Barredo, J.I. Normalised flood losses in Europe: 1970-2006. Nat. Hazards Earth Syst. Sci. 2009, 9, 97-104. [CrossRef]

3. Wallemacq, P.; Guha-Sapir, D.; McClean, D.; CRED; UNISDR. The Human Cost of Weather Related Disasters-1995-2015; CRED \& UNISDR: Brussels, Belgium, 2015.

4. Kummu, M.; de Moel, H.; Ward, P.J.; Varis, O. How close do we live to water? A global analysis of population distance to freshwater bodies. PLoS ONE 2011, 6. [CrossRef] [PubMed]

5. Kreibich, H.; Bubeck, P.; Van Vliet, M.; De Moel, H. A review of damage-reducing measures to manage fluvial flood risks in a changing climate. Mitig. Adapt. Strateg. Glob. Chang. 2015, 20, 967-989. [CrossRef]

6. De Moel, H.; Van Alphen, J.; Aerts, J.C.J.H. Flood maps in Europe-Methods, availability and use. Nat. Hazards Earth Syst. Sci. 2009, 9, 289-301. [CrossRef]

7. Tsakiris, G. Flood risk assessment: Concepts, modelling, applications. Nat. Hazards Earth Syst. Sci. 2014, 14, 1361-1369. [CrossRef]

8. Smith, D. Flood damage estimation A review of urban stage damage curves and loss functions. Water SA 1994, 20, 231-238.

9. Jongman, B.; Kreibich, H.; Apel, H.; Barredo, J.I.; Bates, P.D.; Feyen, L.; Gericke, A.; Neal, J.; Aerts, J.C.J.H.; Ward, P.J. Comparative flood damage model assessment: Towards a European approach. Nat. Hazards Earth Syst. Sci. 2012, 12, 3733-3752. [CrossRef]

10. Huizinga, J.; de Moel, H.; Szewczyk, W. Global Flood Depth-Damage Functions: Methodology and the Database with Guidelines; Publications Office of the European Union: Luxembourg, 2017.

11. Aronica, G.; Bates, P.D.; Horritt, M.S. Assessing the uncertainty in distributed model predictions using observed binary pattern information within GLUE. Hydrol. Process. 2002, 16, 2001-2016. [CrossRef]

12. Papaioannou, G.; Loukas, A.; Vasiliades, L.; Aronica, G.T. Flood inundation mapping sensitivity to riverine spatial resolution and modelling approach. Nat. Hazards 2016, 83, 117-132. [CrossRef]

13. Teng, J.; Jakeman, A.J.; Vaze, J.; Croke, B.F.W.; Dutta, D.; Kim, S. Flood inundation modelling: A review of methods, recent advances and uncertainty analysis. Environ. Model. Softw. 2017, 90, 201-216. [CrossRef]

14. Horritt, M.S.; Bates, P.D. Evaluation of 1D and 2D numerical models for predicting river flood inundation. J. Hydrol. 2002, 268, 87-99. [CrossRef]

15. Néelz, S.; Pender, G. Desktop Review of 2D Hydraulic Modelling Packages; Environment Agency: Bristol, UK, 2009.

16. Neelz, S.; Pender, G.; Wright, N.G. Benchmarking of 2D Hydraulic Modelling Packages; Environment Agency: Bristol, UK, 2010. 
17. Neelz, S.; Pender, G. Benchmarking the Latest Generation of 2D Hydraulic Modelling Packages; Environment Agency: Bristol, UK, 2013.

18. Papaioannou, G.; Vasiliades, L.; Loukas, A.; Aronica, G.T. Probabilistic flood inundation mapping at ungauged streams due to roughness coefficient uncertainty in hydraulic modelling. Adv. Geosci. 2017, 44, 23-34. [CrossRef]

19. Bathrellos, G.D.; Skilodimou, H.D.; Soukis, K.; Koskeridou, E. Temporal and spatial analysis of flood occurrences in the drainage basin of Pinios River (Thessaly, Central Greece). Land 2018, 7, 106. [CrossRef]

20. Diakakis, M.; Mavroulis, S.; Deligiannakis, G. Floods in Greece, a statistical and spatial approach. Nat. Hazards 2012, 62, 485-500. [CrossRef]

21. Mimikou, M.; Koutsoyiannis, D. Extreme floods in Greece: The case of 1994. In Proceedings of the U.S.-ITALY Research Workshop on the Hydrometeorology, Impacts, and Management of Extreme Floods, Perugia, Italy, 13-17 November 1995; pp. 13-17.

22. Ettema, R. (Ed.) Hydraulic Modeling: Concepts and Practice; American Society of Civil Engineers: Reston, VA, USA, 2000; ISBN 978-0-7844-7041-1.

23. Nkwunonwo, U.C.; Whitworth, M.; Baily, B. A review of the current status of flood modelling for urban flood risk management in the developing countries. Sci. Afr. 2020, 7, e00269. [CrossRef]

24. Falter, D.; Dung, N.V.; Vorogushyn, S.; Schröter, K.; Hundecha, Y.; Kreibich, H.; Apel, H.; Theisselmann, F.; Merz, B. Continuous, large-scale simulation model for flood risk assessments: Proof-of-concept. J. Flood Risk Manag. 2016, 9, 3-21. [CrossRef]

25. De Paiva, R.C.D.; Buarque, D.C.; Collischonn, W.; Bonnet, M.P.; Frappart, F.; Calmant, S.; Bulhões Mendes, C.A. Large-scale hydrologic and hydrodynamic modeling of the Amazon River basin. Water Resour. Res. 2013, 49, 1226-1243. [CrossRef]

26. Neal, J.; Schumann, G.; Bates, P. A subgrid channel model for simulating river hydraulics and floodplain inundation over large and data sparse areas. Water Resour. Res. 2012, 48,1-16. [CrossRef]

27. Biancamaria, S.; Bates, P.D.; Boone, A.; Mognard, N.M. Large-scale coupled hydrologic and hydraulic modelling of the Ob river in Siberia. J. Hydrol. 2009, 379, 136-150. [CrossRef]

28. Klimeš, J.; Benešová, M.; Vilímek, V.; Bouška, P.; Cochachin Rapre, A. The reconstruction of a glacial lake outburst flood using HEC-RAS and its significance for future hazard assessments: An example from Lake 513 in the Cordillera Blanca, Peru. Nat. Hazards 2014, 71, 1617-1638. [CrossRef]

29. Greenberg, R.J. Dam Breach Model of Lake Anza Dam Using Hec-Ras; California State University: Sacramento, CA, USA, 2018.

30. Pathak, C.S.; Teegavarapu, R.S.V.; Olson, C.; Singh, A.; Lal, A.M.W.; Polatel, C.; Zahraeifard, V.; Senarath, S.U.S. Uncertainty Analyses in Hydrologic/Hydraulic Modeling: Challenges and Proposed Resolutions. J. Hydrol. Eng. 2015, 20, 02515003. [CrossRef]

31. Annis, A.; Nardi, F.; Volpi, E.; Fiori, A. Quantifying the relative impact of hydrological and hydraulic modelling parameterizations on uncertainty of inundation maps. Hydrol. Sci. J. 2020, 65, 507-523. [CrossRef]

32. Hellenic National Meteorological Service the Climate of Greece. Available online: http:/ /www.emy.gr/emy/en/climatology / climatology (accessed on 16 April 2021).

33. Beck, H.E.; Zimmermann, N.E.; Mcvicar, T.R.; Vergopolan, N.; Berg, A.; Wood, E.F. Data Descriptor: Present and future Köppen-Geiger climate classi fi cation maps at 1-km resolution. Sci. Data 2018, 1-12. [CrossRef]

34. Special Secretariat for Water. Ministry of Environment and Energy (SSW-MEE) Flood Risks for River Basins in Epirous Region. In Analysis of Area Characteristics and Flood Mechanisms; Special Secretariat for Water, Ministry of Environment and Energy (SSW-MEE): Athens, Greece, 2015.

35. Lekka, E.; Kagalou, I.; Lazaridou-Dimitriadou, M.; Albanis, T.; Dakos, V.; Lambropoulou, D.; Sakkas, V. Assessment of the water and habitat quality of a Mediterranean river (Kalamas, Epirus, Hellas), in accordance with the EU water framework directive. Acta Hydrochim. Hydrobiol. 2004, 32, 175-188. [CrossRef]

36. Weather-Atlas. Available online: https://www.weather-atlas.com/en/greece/ioannina-weather-october (accessed on 8 January 2021).

37. CLIMATE-DATA.ORG. Available online: https://en.climate-data.org/europe/greece/ioannina/ioannina-1375/ (accessed on 8 January 2021).

38. Zikakou, I. Flooding on Ioannina Lake Island. Available online: https://greece.greekreporter.com/2014/12/09/flooding-onioannina-lake-island/ (accessed on 12 June 2020).

39. Davies, R. Greece-Floods in North West Leave 1 Dead. Available online: http:/ / floodlist.com/europe/greece-floods-corfuepirus-november-2017 (accessed on 12 June 2020).

40. Loukas, A.; Vasiliades, L. Probabilistic analysis of drought spatiotemporal characteristics in Thessaly region, Greece. Nat. Hazards Earth Syst. Sci. 2004, 4, 719-731. [CrossRef]

41. Vasiliades, L.; Loukas, A.; Liberis, N. A Water Balance Derived Drought Index for Pinios River Basin, Greece. Water Resour. Manag. 2011, 25, 1087-1101. [CrossRef]

42. Dimitriadis, P.; Tegos, A.; Oikonomou, A.; Pagana, V.; Koukouvinos, A.; Mamassis, N.; Koutsoyiannis, D.; Efstratiadis, A. Comparative evaluation of $1 \mathrm{D}$ and quasi-2D hydraulic models based on benchmark and real-world applications for uncertainty assessment in flood mapping. J. Hydrol. 2016, 534, 478-492. [CrossRef]

43. Ameziane, T.; Belghiti, M.; Benbeniste, S.; Bergaoui, M.; Bonaccorso, B.; Cancelliere, A.; Christofides, T.; Cubillo, F.; Euchi, L.; Gabiña, D.; et al. Drought Management Instructions; European Commission: Brussels, Belgium, 2007. 
44. Davies, R. Greece-Evacuations after Floods in Thessaly. Available online: http:/ /floodlist.com/europe/greece-floods-thessalyfebruary-march-2018 (accessed on 1 February 2019).

45. Copernicus-Mapping Emergency Management Service EMSR271: Floods in Central Greece. Available online: https:// emergency.copernicus.eu/mapping/list-of-components/EMSR271/ALL/ALL (accessed on 1 February 2019).

46. Special Secretariat for Water. Ministry of Environment and Energy (SSW-MEE) Flood Risks for River Basins in Thessaly Region. In Analysis of Area Characteristics and Flood Mechanisms; Special Secretariat for Water, Ministry of Environment and Energy (SSW-MEE): Athens, Greece, 2017.

47. Psomiadis, E.; Soulis, K.X.; Zoka, M.; Dercas, N. Synergistic approach of remote sensing and gis techniques for flash-flood monitoring and damage assessment in Thessaly plain area, Greece. Water 2019, 11, 448. [CrossRef]

48. Papaioannou, G.; Efstratiadis, A.; Vasiliades, L.; Loukas, A.; Papalexiou, S.; Koukouvinos, A.; Tsoukalas, I.; Kossieris, P. An Operational Method for Flood Directive Implementation in Ungauged Urban Areas. Hydrology 2018, 5, 24. [CrossRef]

49. Efstratiadis, A.; Papalexiou, S.M.; Markonis, I.; Mamassis, N. Management Plans of Flood Risks for River Basins in Epirous, Greece (GR08)-Phase A-Ombrian Curves; Special Secretariat for Water, Ministry of Environment and Energy (SSW-MEE): Athens, Greece, 2015.

50. Koutsoyiannis, D. A stochastic disaggregation method for design storm and flood synthesis. J. Hydrol. 1994, 156, 193-225. [CrossRef]

51. Sutcliffe, J.V. Methods of Flood Estimation: A Guide to the Flood Studies Report; Institute of Hydrology: Wallingford, UK, 1978.

52. Chow, V.; Maidment, D.; Mays, L. Applied Hydrology; McGraw-Hill: Singapore, 1988.

53. Koutsoyiannis, D.; Xanthopoulos, T. Engineering Hydrology, 3rd ed.; National Technical University of Athens: Athens, Greece, 1999.

54. Efstratiadis, A.; Koussis, A.D.; Koutsoyiannis, D.; Mamassis, N. Flood design recipes vs. reality: Can predictions for ungauged basins be trusted? Nat. Hazards Earth Syst. Sci. 2014, 14, 1417-1428. [CrossRef]

55. Michailidi, E.M.; Antoniadi, S.; Koukouvinos, A.; Bacchi, B.; Efstratiadis, A. Timing the time of concentration: Shedding light on a paradox. Hydrol. Sci. J. 2018, 63, 721-740. [CrossRef]

56. Mockus, V.; McKeever, V.; Owen, W.; Rallison, R. Design Hydrographs. In National Engineering Handbook. Available online: https:/ / directives.sc.egov.usda.gov/OpenNonWebContent.aspx?content=18393.wba (accessed on 1 February 2019).

57. Feldman, A.D. Hydrologic Modeling System Technical Reference Manual; US Army Corps of Engineers-Hydrologic Engineering Center: Davis, CA, USA, 2000.

58. Dottori, F.; Di Baldassarre, G.; Todini, E. Detailed data is welcome, but with a pinch of salt: Accuracy, precision, and uncertainty in flood inundation modeling. Water Resour. Res. 2013, 49, 6079-6085. [CrossRef]

59. Brunner, G.W. HEC-RAS River Analysis System-Hydraulic Reference Manual, Version 5.0; US Army Corps of Engineers-Hydrologic Engineering Center: Davis, CA, USA, 2016; p. 547.

60. da Paz, A.R.; Collischonn, W.; Tucci, C.E.M.; Padovani, C.R. Large-scale modelling of channel flow and floodplain inundation dynamics and its application to the Pantanal (Brazil). Hydrol. Process. 2011, 25, 1498-1516. [CrossRef]

61. Tsubaki, R.; Fujita, I. Unstructured grid generation using LiDAR data for urban flood inundation modelling. Hydrol. Process. 2010, 24, 1404-1420. [CrossRef]

62. Teng, J.; Vaze, J.; Dutta, D.; Marvanek, S. Rapid Inundation Modelling in Large Floodplains Using LiDAR DEM. Water Resour. Manag. 2015, 29, 2619-2636. [CrossRef]

63. Leitão, J.P.; de Sousa, L.M. Towards the optimal fusion of high-resolution Digital Elevation Models for detailed urban flood assessment. J. Hydrol. 2018, 561, 651-661. [CrossRef]

64. Bhuyian, M.N.M.; Kalyanapu, A. Accounting digital elevation uncertainty for flood consequence assessment. J. Flood Risk Manag. 2018, 11, S1051-S1062. [CrossRef]

65. Bates, P.D.; De Roo, A.P.J. A simple raster-based model for flood inundation simulation. J. Hydrol. 2000, 236, 54-77. [CrossRef]

66. Bharath, R.; Elshorbagy, A. Flood mapping under uncertainty: A case study in the Canadian prairies. Nat. Hazards 2018, 94, 537-560. [CrossRef]

67. Liu, Z.; Merwade, V. Accounting for model structure, parameter and input forcing uncertainty in flood inundation modeling using Bayesian model averaging. J. Hydrol. 2018, 565, 138-149. [CrossRef]

68. Haltas, I.; Tayfur, G.; Elci, S. Two-dimensional numerical modeling of flood wave propagation in an urban area due to Ürkmez dam-break, İzmir, Turkey. Nat. Hazards 2016, 81, 2103-2119. [CrossRef]

69. Liu, Z.; Merwade, V.; Jafarzadegan, K. Investigating the role of model structure and surface roughness in generating flood inundation extents using one- and two-dimensional hydraulic models. J. Flood Risk Manag. 2019, 12. [CrossRef]

70. Brown, J.D.; Spencer, T.; Moeller, I. Modeling storm surge flooding of an urban area with particular reference to modeling uncertainties: A case study of Canvey Island, United Kingdom. Water Resour. Res. 2007, 43, 1-22. [CrossRef]

71. Schubert, J.E.; Sanders, B.F. Building treatments for urban flood inundation models and implications for predictive skill and modeling efficiency. Adv. Water Resour. 2012, 41, 49-64. [CrossRef]

72. Bellos, V.; Tsakiris, G. Comparing Various Methods of Building Representation for 2D Flood Modelling In Built-Up Areas. Water Resour. Manag. 2015, 29, 379-397. [CrossRef]

73. Shen, J.; Tan, F.; Zhang, Y. Improved building treatment approach for urban inundation modeling: A case study in Wuhan, China. Water 2018, 10, 1760. [CrossRef] 
74. Special Secretariat for Water. Ministry of Environment and Energy (SSW-MEE). In Preliminary Flood Risk Assessments; Special Secretariat for Water, Ministry of Environment and Energy (SSW-MEE): Athens, Greece, 2013.

75. European Commission European Overview_Flood Risk Management Plans Accompanying; European Commission: Brussels, Belgium, 2019.

76. US Army Corps of Engineers-Hydrologic Engineering Center HEC-HMS Technical Reference ManualChannel—FlowCurrentMuskingum Model. Available online: https://www.hec.usace.army.mil/confluence/hmsdocs/hmstrm/channel-flow/ muskingum-model (accessed on 2 March 2021).

77. Brunner, G.W. CEIWR-HEC HEC-RAS River Analysis System 2D Modeling User's Manual; US Army Corps of Engineers-Hydrologic Engineering Center: Davis, CA, USA, 2016.

78. European Environment Agency Disasters in Europe: More Frequent and Causing More Damage; European Environment Agency: Copenhagen, Denmark, 2011.

79. Papaioannou, G. Flood Hazard and Risk Modelling Framework for Ungauged Streams and Watersheds; University of Thessaly: Volos, Greece, 2017.

80. Alamanos, A.; Latinopoulos, D.; Loukas, A.; Mylopoulos, N. Comparing Two Hydro-Economic Approaches for Multi-Objective Agricultural Water Resources Planning. Water Resour. Manag. 2020, 34, 4511-4526. [CrossRef]

81. Fletcher, S.; Strzepek, K.; Alsaati, A.; De Weck, O. Learning and flexibility for water supply infrastructure planning under groundwater resource uncertainty. Environ. Res. Lett. 2019, 14. [CrossRef]

82. Islam, Z. Literature Review on Physically Based Hydrologic Modeling; University of Alberta: Edmonton, AB, Canada, 2011. 